\title{
Metabolic engineering of Yarrowia lipolytica for thermoresistance and enhanced erythritol productivity
}

\author{
Nan Wang ${ }^{1 \dagger}$, Ping $\mathrm{Chi}^{1 \dagger}$, Yawen Zou ${ }^{1 \dagger}$, Yirong Xu', Shuo Xu ${ }^{1}$, Muhammad Bilal ${ }^{2}$, Patrick Fickers ${ }^{3}$ \\ and Hairong Cheng ${ }^{1 *}$ (D)
}

\begin{abstract}
Background: Functional sugar alcohols have been widely used in the food, medicine, and pharmaceutical industries for their unique properties. Among these, erythritol is a zero calories sweetener produced by the yeast Yarrowia lipolytica. However, in wild-type strains, erythritol is produced with low productivity and yield and only under high osmotic pressure together with other undesired polyols, such as mannitol or D-arabitol. The yeast is also able to catabolize erythritol in non-stressing conditions.
\end{abstract}

Results: Herein, Y. lipolytica has been metabolically engineered to increase erythritol production titer, yield, and productivity from glucose. This consisted of the disruption of anabolic pathways for mannitol and D-arabitol together with the erythritol catabolic pathway. Genes ZWF1 and GND encoding, respectively, glucose-6-phosphate dehydrogenase and 6-phosphogluconate dehydrogenase were also constitutively expressed in regenerating the $\mathrm{NADPH}_{2}$ consumed during erythritol synthesis. Finally, the gene RSP5 gene from Saccharomyces cerevisiae encoding ubiquitin ligase was overexpressed to improve cell thermoresistance. The resulting strain $\mathrm{HCY} 118$ is impaired in mannitol or D-arabitol production and erythritol consumption. It can grow well up to $35^{\circ} \mathrm{C}$ and retain an efficient erythritol production capacity at $33^{\circ} \mathrm{C}$. The yield, production, and productivity reached $0.63 \mathrm{~g} / \mathrm{g}, 190 \mathrm{~g} / \mathrm{L}$, and $1.97 \mathrm{~g} / \mathrm{L} \cdot \mathrm{h}$ in 2-L flasks, and increased to $0.65 \mathrm{~g} / \mathrm{g}, 196 \mathrm{~g} / \mathrm{L}$, and $2.51 \mathrm{~g} / \mathrm{L} \cdot \mathrm{h}$ in $30-\mathrm{m}^{3}$ fermentor, respectively, which has economical practical importance.

Conclusion: The strategy developed herein yielded an engineered $Y$. lipolytica strain with enhanced thermoresistance and NADPH supply, resulting in a higher ability to produce erythritol, but not mannitol or D-arabitol from glucose. This is of interest for process development since it will reduce the cost of bioreactor cooling and erythritol purification.

Keywords: Erythritol, Erythritol dehydrogenase, Mannitol dehydrogenase, Thermoresistance, Yarrowia lipolytica

\section{Background}

In industrialized countries, the overconsumption of sucrose and other specialties including honey, maple syrup, or high fructose corn syrup causes overweight,

\footnotetext{
*Correspondence: chrqra@sjtu.edu.cn

${ }^{\dagger}$ Nan Wang, Ping Chi and Yawen Zou contributed equally to this work

${ }^{1}$ State Key Laboratory of Microbial Metabolism, and School of Life

Sciences and Biotechnology, Shanghai Jiao Tong University, Shanghai,

China

Full list of author information is available at the end of the article
}

obesity, diabetes, and metabolic syndrome $[1,2]$. As an alternative sweetener, low or non-caloric molecules, such as sugar alcohol, are more and more considered. Among them, erythritol (1,2,3,4-butanetetrol) is a four-carbon polyol with several exciting features. It has very low digestibility and does not raise the blood insulin level. It reduces lipid peroxidation, thereby protecting the damage caused by oxidative stress involved in the pathogenesis of diabetes [3]. It is not metabolized by Streptococcus mutans, the main causative agent of tooth decay. Erythritol has been determined as safe for human consumption 
even at high doses. The maximal recommended dose ranges between 0.6 and $0.8 \mathrm{~g} / \mathrm{kg}$ of body weight, while it is only around $0.3 \mathrm{~g} / \mathrm{kg}$ of body weight for the sweetener xylitol [4]. It can also act as an antioxidant in vivo and displays endothelium-protective effects, which may help to protect against hyperglycemia-induced vascular damage [5]. Due to endothelium-protective effects during hyperglycemia, erythritol can reduce the risk of diabetic complications [6].

Erythritol is predominantly produced from glucose by osmophilic yeast such as Candida magnoliae, Y. lipolytica, Torula sp., Moniliella megachiliensis, or Trichosporonoides oedocephalis [7-10]. Among these, Y. lipolytica is the most widely used for industrial erythritol production. Using metabolic engineering, much progress has been gained to improve the erythritol production titer in Y. lipolytica. For instance, Janek et al. [11] found that overexpression of the endogenous erythrose reductase gene (i.e., ER, YALIOF18590g) resulted in an enhanced erythritol production with the titer of $44.44 \mathrm{~g} / \mathrm{L}$, a yield of $0.44 \mathrm{~g} / \mathrm{g}$, and productivity of $0.77 \mathrm{~g} / \mathrm{L} / \mathrm{h}$, which was $20 \%$ higher than the parental strain. Carly et al. [12] constructed the $Y$. lipolytica mutant FCY218 by overexpressing GUT1 (encoding a glycerol kinase, YALIOFO0484g) and TKL1 gene (encoding a transketolase, YALIOEO6479g) and by disrupting the EYK1 gene (encoding erythrulose kinase, YALIOF01606g). The engineered strain exhibited a $75 \%$ higher erythritol production titer as compared to that of wild type $(80.6 \mathrm{~g} / \mathrm{L})$. In Y. lipolytica strain CGMCC7326, overexpression of two erythrose reductase genes (ER10, YALIOD07634g, and ER25, $Y A L 10 C 13508 \mathrm{~g}$ ) and engineering of the NADPH cofactor metabolism by overexpression of 6-phosphogluconate dehydrogenase genes (GND1, YALIOB15598g) and glucose-6-phosphate dehydrogenase genes (ZWF1, YALIOE22649g) led to a significant increase in erythritol titer and yield as compared to the wild-type strain (i.e., $190 \mathrm{~g} / \mathrm{L}$ and $0.63 \mathrm{~g} / \mathrm{g}$, respectively) [13]. However, the erythritol production process still suffers from several drawbacks, such as the production of unwanted byproducts such as mannitol and D-arabitol, which renders the purification process more challenging. In these processes, the bioreactor cooling cost could not be neglected at a large scale. Therefore, the improvement of the thermotolerance of the producing strain must also be considered.

To optimize strain CGMCC7326 for erythritol production, it has been impaired for the ability to synthesize mannitol and D-arabitol and to catabolize erythritol. For that purpose, we first identify five genes, namely AraDH1 (g1595.t1, YALIOF02211g), AraDH2 (g3858. t1, YALIOE05643g), MDH1 (g5130.t1, YALIOB16192g), MDH2 (g2069.t1, YALIOD18964g), XDH1 (g4121.t1, YALIOE12463g) and characterized them with D-mannitol or $\mathrm{D}$-arabitol dehydrogenase activities. Then, the $\mathrm{D}$-mannitol dehydrogenase gene that is mainly responsible for byproducts synthesis was deleted, together with gene EYD1 encoding erythritol dehydrogenase (g1570. t1, YALIOF01650g) to disrupt the erythritol utilization pathway. Thirdly, the $r s p 5$ gene from S. cerevisiae encoding ubiquitin ligase was overexpressed, allowing the cell to grow at $35{ }^{\circ} \mathrm{C}$. As the synthesis of erythritol is not a redox-balance reaction, $Z W F 1$ and GND1 genes were overexpressed in Y. lipolytica, to recycle cofactor NADP. We also disrupt gene Ku70 involved in non-homologous end-joining to facilitate gene disruption procedure.

\section{Results and discussion \\ Construction of a chassis strain derived from $Y$. lipolytica CGMCC7326}

We previously engineered the wild-type strain CGMCC7326 for erythritol production using hygromycin resistance for transformant selection [13]. However, no further genetic modifications could be operated in the resulting strain $\mathrm{HCY} 108$ as it is resistant to hygromycin and lacks auxotrophic markers. Therefore, we intended to construct a chassis strain allowing multiple genome editions. For that purpose, we first disrupted gene $K u 70$ (YALIOC08701g) involved in non-homologous end-joining (NHEJ) to facilitate subsequent gene disruption. We also rendered the resulting strain auxotrophic for uracil by disrupting the URA3 gene (U40564.1) encoding orotidine $5^{\prime}$-phosphate decarboxylase.

In Y. lipolytica, NHEJ, the dominant form of DNA repair, is mediated by the heterodimer protein complex Ku70/Ku80 [14, 15]. It has been reported that the disruption of gene encoding Ku70 resulted in the loss of NHEJ repair and an increased rate of homologous recombination (HR) [16, 17]. Therefore, Ku70 disruption significantly increases the rate of correct targeted gene replacement to generate knock-out and knock-in mutants, and hence improve the precision of genetic edition in $Y$. lipolytica. The disruption cassette contained upstream and downstream fragments of the Ku70 gene and the hygromycin resistance gene flanked by loxP and loxR sequences [18]. The Ku70 disrupted strain was then cured of the hygromycin resistance gene by transient expression of the Cre gene encoding loxR/loxP recombinase [18]. This yielded strain HCY109 (ery929 $\Delta k u 70$ ) (Table 1).

In Y. lipolytica and other yeasts, the URA3 gene encoding orotidine $5^{\prime}$-monophosphate decarboxylase (OMP) involved in uracil synthesis has been used as a sensitive and versatile auxotrophic marker [18]. Therefore, $U R A 3$ was disrupted in strain HCY109 by gene replacement using a defective allele and a selection medium containing 5-fluoroorotic acid (5-FOA). The resulting chassis 
Table 1 Strains, gene cassettes, and primers used in this study

\begin{tabular}{|c|c|c|}
\hline Strains/plasmids/primers & Genotype/sequences $\left(5^{\prime} \rightarrow 3^{\prime}\right)$ & References/restriction sites \\
\hline \multicolumn{3}{|l|}{ E. coli strain } \\
\hline BL21(DE3) & $\begin{array}{l}\text { B F- ompT gal dcm lon hsdS } S_{B}\left(r_{B}^{-} m_{B}^{-}\right) \lambda(\text { DE3 [lacl lacUV5- } \\
\text { T7p07 ind1 sam7 nin5]) }\left[\mathrm{malB}^{+}\right]_{\mathrm{K}-12}\left(\lambda^{S}\right) \text { pLysS }\end{array}$ & New England BioLabs \\
\hline TOP10 & $\begin{array}{l}\text { F- mcrA } \triangle \text { (mrr-hsdRMS-mcrBC) } \Phi 80 / a c Z \Delta M 15 \\
\Delta l a c X 74 \text { recA1 araD139 } \triangle \text { (ara leu) } \\
7697 \text { galU galK rpsL endA1 nupG }\end{array}$ & Thermo Fisher Scientific \\
\hline $\mathrm{BL} 21 / \mathrm{AraDH} 1$ & BL21(DE3) pET28a-AraDH1 & This work \\
\hline BL21/AraDH2 & BL21(DE3) pET28a-AraDH2 & This work \\
\hline BL21/MDH1 & BL21(DE3) pET28a-MDH1 & This work \\
\hline BL21/MDH2 & BL21(DE3) pET28a-MDH2 & This work \\
\hline $\mathrm{BL} 21 / \mathrm{XDH} 1$ & BL21(DE3) pET28a-XDH1 & This work \\
\hline \multicolumn{3}{|l|}{ Y. lipolytica strains } \\
\hline HCY107 (CGMCC7326, or ery929) & Suc-, Lac-, Mal- & Cheng et al., 2018 \\
\hline HCY109 & CGMCC7326 derivative, ery919 $\Delta$ ku70 & This work \\
\hline HCY109-2 & HCY109 derivative, $\triangle$ ku70 $\triangle$ ura3 & This work \\
\hline HCY110 & HCY109 derivative, $\triangle k u 70 \triangle A r a D H 1$ & This work \\
\hline HCY111 & HCY109 derivative, $\triangle k u 70 \triangle A r a D H 2$ & This work \\
\hline $\mathrm{HCY} 112$ & HCY109 derivative, $\triangle k u 70 \triangle m d h 1$ & This work \\
\hline HCY113 & HCY109 derivative, $\triangle k u 70 \Delta$ ura $3 \Delta m d h 2$ & This work \\
\hline HCY114 & HCY109 derivative, $\triangle k u 70 \Delta x d h 1$ & This work \\
\hline HCY115 & $\mathrm{HCY} 113$ derivative, $\triangle k u 70 \Delta u r a 3 \Delta m d h 2 \Delta$ eyd 1 & This work \\
\hline HCY117 & HCY116 derivative, $\triangle k u 70 \Delta m d h 2 \Delta$ eyd1::Sc.rsp5 & This work \\
\hline HCY118 & $\begin{array}{l}\text { HCY117derivative, } \triangle k u 70 \Delta m d h 2 \Delta \text { eyd1::Sc. } \\
\text { rsp5::zwf1::gnd1 }\end{array}$ & This work \\
\hline \multicolumn{3}{|l|}{ Plasmids } \\
\hline pUC19 & LacZ, Amp ${ }^{R}$ & \\
\hline pET28a & Lacl, T7 promoter, Kan ${ }^{R}$ & Novagen \\
\hline pET28a-ylAraDH1 & Containing y/AraDH1 gene g1595.t1 (YALIOF02211g) & This work \\
\hline pET28a-ylAraDH2 & Containing y/AraDH2 gene g3858.t1 (YALIOE05643g) & This work \\
\hline pET28a-yIMDH1 & Containing y/MDH1 gene g5130.t1 (YALIOB16192g) & This work \\
\hline pET28a-yIMDH2 & Containing yIMDH2 gene g2069.t1 (YALI0D18964g) & This work \\
\hline pET28a-yIXDH1 & Containing yIXDH1 gene g4121.t1 (YALIOE12463g) & This work \\
\hline $\begin{array}{l}\text { The above plasmids (except } \mathrm{pUC} 19 \text { an } \\
\text { yIXDH1 recombinant enzymes }\end{array}$ & used to transform BL21(DE3) and in the production of yIAraDH1, y/AraDH2, y & yIMDH1, y/MDH2 and \\
\hline pHB4-621XDH & pHB4-Cre derivative, $h p 4 d-621 X D H-T T-h p 4 d-C r e$ & This work \\
\hline pWSV-Ku70-loxP-hph-loxP & up Ku70-loxP-pLeu2-hph-TT-loxP-dw Ku>0 & This work \\
\hline pWSV-AraDH1-loxP-hph-loxP & up AraDH1-loxP-pLeu2-hph-TT-IoxP-dw AraDH1 & This work \\
\hline pWSV-AraDH2-loxP-hph-loxP & up AraDH2-loxP-pLeu2-hph-TT-loxP-dw AraDH2 & This work \\
\hline pWSV-MDH1-loxP-hph-loxP & up MDH1-IoxP-pLeu2-hph-TT-IoxP-dw MDH1 & This work \\
\hline pWSV-MDH2-loxP-hph-loxP & up MDH2-IoxP-pLeu2-hph-TT-loxP-dw MDH2 & This work \\
\hline pWSV-XDH1-loxP-hph-loxP & up XDH1-IoxP-pLeu2-hph-TT-IoxP-dwXDH1 & This work \\
\hline pWSV-EYD1-loxP-hph-loxP & up EYD1-IoxP-pLeu2-hph-TT-IoxP-dw EYD1 & This work \\
\hline PINA1313-RSP5 & up zeta-ura3-hp4d-RSP5-TT-dw zeta & This work \\
\hline The above plasmids are used to delete & IraDH2, yIMDH1, yIMDH2, yIXDH1,PGI genes and overexpress Sc.rsp5 gene for & rerythritol synthesis \\
\hline Primers & Sequences $\left(5^{\prime} \rightarrow 3^{\prime}\right)$ & Restriction sites \\
\hline Primers used for amplification of ylArc & 2. yIMDH1, yIMDH2 and yIXDH1 genes and cloned to pET28a by Gibson assem & mbly \\
\hline$P_{28 a-y \mid A r a D H 1-F}$ & CTGGTGCCGCGCGGCAGCCATATGTCTCTCTTTTCACTCGCCAAGAAAAC & Ndel \\
\hline$P_{28 a-y \mid A r a D H 1-R}$ & GTGGTGGTGGTGGTGGTGCTCGAGTTACCAGATGGTGTAACCTCCATCGAC & Xhol \\
\hline$P_{28 a-y \mid A r a D H 2-F}$ & CTGGTGCCGCGCGGCAGCCATATGTCCAACTCCGCCAAAGCCGCTGTC & Ndel \\
\hline$\underline{P}_{28 a-y \mid A r a D H 2-R}$ & GTGGTGGTGGTGGTGGTGCTCGAGTTAAATAATAGTGTAACCACCATCAATG & Xhol \\
\hline
\end{tabular}


Table 1 (continued)

\begin{tabular}{|c|c|c|}
\hline Primers & Sequences $\left(5^{\prime} \rightarrow 3^{\prime}\right)$ & Restriction sites \\
\hline$P_{28 a-y \mid M D H 1-F}$ & CTGGTGCCGCGCGGCAGCCATATGCCTGCACCAGCAACCTACGCTAC & Ndel \\
\hline$P_{28 a-y I M D H 1-R}$ & GTGGTGGTGGTGGTGGTGCTCGAGCTAAGGACAACAGTAGCCGCCATCAAC & Xhol \\
\hline$P_{28 a-y I M D H 2-F}$ & CTGGTGCCGCGCGGCAGCCATATGATGTCTGGACCTTCCACCCTCGCCAC & Ndel \\
\hline$P_{28 a-y \mid M D H 2-R}$ & GTGGTGGTGGTGGTGGTGCTCGAGCTAAGGAGCGCAGTAGCCACCATCGAC & Xhol \\
\hline$P_{28 a-y \mid X D H 1-F}$ & CTGGTGCCGCGCGGCAGCCATATGTCTTCTAACCCGTCATTTGTTCTTC & Ndel \\
\hline$P_{28 a-y \mid X D H 1-R}$ & GTGGTGGTGGTGGTGGTGCTCGAGCTACTCCTCCTCGGGACCGTCAATGATG & Xhol \\
\hline \multicolumn{3}{|c|}{ The below primers are used for verification of KU70, yIAraDH1, yIAraDH2, yIMDH1, yIMDH2, yIXDH1, yIEYD1, pgi genes knockout in Y. lipolytica } \\
\hline$P_{\text {Ku70-knockout }-F}$ & ATGGAATGGATTTCACATCTGGAGAACG & \\
\hline$P_{\text {Ku70-knockout }-R}$ & TCACTTCCCATAGTACTTTTTGACCAC & \\
\hline$P_{\text {AraDH1-knockout }-\mathrm{F}}$ & ATGTCTCTCTTTTCACTCGCCAAGAAAAC & \\
\hline$P_{\text {AraDH1-knockout }-R}$ & CTCTTGTGGTGCTCTCGAATGGCCTTGA & \\
\hline$P_{\text {AraDH2-knockout }-\mathrm{F}}$ & ATGTCCAACTCCGCCAAAGCCGCTGTC & \\
\hline$P_{\text {AraDH2- knockout }-R}$ & TTAAATAATAGTGTAACCACCATCAATG & \\
\hline $\mathrm{P}_{\mathrm{MDH1}-\text { knockout }-\mathrm{F}}$ & ATGCCTGCACCAGCAACCTACGCTAC & \\
\hline $\mathrm{P}_{\mathrm{MDH1} \text { - knockout }-\mathrm{R}}$ & CACTGTATTACATCGAGCGAATCCA & \\
\hline $\mathrm{P}_{\mathrm{MDH} 2-\text { knockout }-\mathrm{F}}$ & ATGTCTGGACCTTCCACCCTCGCCAC & \\
\hline $\mathrm{P}_{\mathrm{MDH} 2-\text { knockout }-\mathrm{R}}$ & CTAAGGAGCGCAGTAGCCACCATCGAC & \\
\hline$P_{\mathrm{XDH1} 1-\text { knockout }-\mathrm{F}}$ & ATG TCTTCTAACCCGTCATTTGTTCTTC & \\
\hline$P_{X D H 1-k n o c k o u t-R}$ & CTACTCCTCCTCGGGACCGTCAATGATG & \\
\hline$P_{\text {EYD1-knockout }-F}$ & CGAGACTCCCTCTGAGGAGTTCCTG & \\
\hline$P_{\text {EYD1-knockout }-R}$ & TTACCAGACGTGGTGGCCACCGCAGAC & \\
\hline \multicolumn{3}{|c|}{ The below primers are used to construct URA3 gene disruption cassette and verify the corrected URA3 gene mutant } \\
\hline$P_{\text {URA3-upstream-F }}$ & CTGAAACGTTATCTTATATGAACTCC & \\
\hline PURA3-upstream-R & TTTGGTGGTGAAGAGGAGACTGAAATAAATTTAG & \\
\hline PURA3-downstream-F & CTAAATTTATTTCAGTCTCCTCTTCACCACCAAATATGTAATTTAACTGTGTATATAG & \\
\hline$P_{\text {URA3-downstream-R }}$ & CAGGCCAGTCCCGCCTCTCCTTTC & \\
\hline$P_{\text {URA3-verify-F }}$ & GTGTGCATGATCAAGACCCATATC & \\
\hline$P_{\text {URA3-verify-R }}$ & AGGTCGGTTCTGGGCAATGAAGCC & \\
\hline \multicolumn{3}{|c|}{ Primers used to detect the mRNA levels of yIAraDH1, yIAraDH2, yIMDH1, yIMDH2, yIXDH1 knockout mutants and mRNA levels of Sc.rsp5, yITKL1 at 30-35 ${ }^{\circ} \mathrm{C}$} \\
\hline$P_{\text {AraDH1-qPCR-F }}$ & GGTATCGCAGCTGCCAAGCAGCTTC & \\
\hline$P_{\text {AraDH1-qPCR-R }}$ & GATTCTGTTTCTGTTTCAGAAAC & \\
\hline$P_{\text {AraDH2-qPCR-F }}$ & CGAGCCAACGCCGGATCCAAGGAAG & \\
\hline$P_{\text {AraDH2-qPCR -R }}$ & CTCAATGGCATCCAGACCCAGGTC & \\
\hline $\mathrm{P}_{\mathrm{MDH1}-\mathrm{qPCR}-\mathrm{F}}$ & GTATCCAAGAACATCATGGAGCG & \\
\hline$P_{\text {MDH1-qPCR-R }}$ & CATTTGTAAGCCTTAGATCGGACTCC & \\
\hline $\mathrm{P}_{\mathrm{MDH} 2-\mathrm{QPCR}-\mathrm{F}}$ & TTCCCCACCAACATCATGGACCG & \\
\hline$P_{M D H 2-q P C R-R}$ & CTTGTAGGCCTTGGCCTTGACGCC & \\
\hline$P_{X D H 1-q P C R-F}$ & TGCGGCTCGGATGTCCACTACTATC & \\
\hline$P_{X D H 1-q P C R-R}$ & GTTGTATCGTCCCTCCTTGTACTC & \\
\hline$P_{\text {rsp5-qPCR-F }}$ & TCCGCAGCGAAGAAAACGTTAAATC & \\
\hline$P_{\text {rsp5-qPCR-R }}$ & GTCTACCACTCGATGTAGCAGTATC & \\
\hline$P_{\text {tkl-qPCR-F }}$ & AAGACTCCCGGCCACCCCGAGGCTG & \\
\hline$P_{\text {tkl-aPCR-R }}$ & CTCCGAAGATGCAGTAAGTGTAGTT & \\
\hline$P_{\beta \text {-actin-up }}$ & ACTCTGGTGATGGTGTCACCCACG & \\
\hline $\mathrm{P}_{\beta \text {-actin-down }}$ & TCGGACGATTTCTCGCTCGGCGGAG & \\
\hline
\end{tabular}


strain was designated HCY109-2 (ery929 $\Delta$ ku70 $\Delta u r a 3$ ) (Table 1). Figure 1 shows the schematic flow to obtain the URA3 disruption mutant.

\section{Identification of genes encoding enzymes with mannitol/D-arabitol dehydrogenase activities in $Y$. lipolytica CGMCC7326}

Although $Y$. lipolytica is one of the best erythritol producers, it also presents some drawbacks such as the synthesis of byproducts including mannitol and D-arabitol. This negatively impacts the yield from glucose and complexifies the purification steps [9, 13, 19-22]. Therefore, we thought of constructing a strain unable to produce these byproducts.

In Ascomycetes fungi, the mannitol cycle consists of two pathways [23]. In the first one, fructose-6P from glycolysis is converted into mannitol-1P by a $\operatorname{NAD}(\mathrm{H})$ dependent mannitol dehydrogenase (Mpd). It is then dephosphorylated into mannitol by a mannitol-1P phosphatase. In the second pathway, fructose is oxidized into mannitol by a reversible $\mathrm{NADP}(\mathrm{H})$-dependent mannitol 2-dehydrogenase (Mdh). In Y. lipolytica, the mannitol dehydrogenase encoded by gene YALIOB16192 $g$ has been characterized as an Mdh [24]. Indeed, its disruption impairs mannitol production from fructose, but not from glycerol or glucose. By contrast, its overexpression slightly improves mannitol production from fructose [23]. These findings pointed out that other pathways may exist to produce mannitol from glucose through fructose-6P, such as an Mpd-Mpp like pathway [23]. However, genes involved in that pathway remain unknown in Y. lipolytica. D-Arabitol is produced by an arabitol dehydrogenase(s) from ribulose, which is obtained by dephosphorylation of ribulose-5P, an intermediate of the pentose phosphate pathway.

Before disrupting these biosynthetic pathways, the first step was to identify those genes involving mannitol and/ or D-arabitol biosynthesis. Genome mining for mannitol dehydrogenase by Dulermo et al. [23] led to the identification of two additional genes, namely YALIOD18964g and $Y A L I O B 16192 g$ that were not characterized so far. Further blast analysis, using gene $X P \_001387287$ from

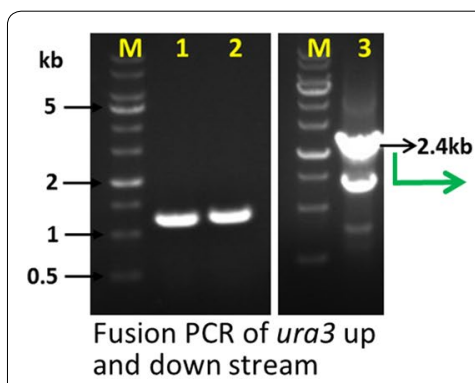

a

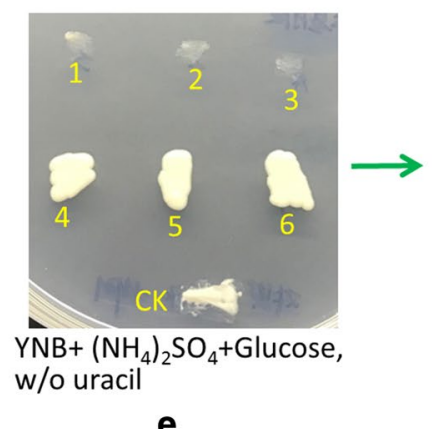

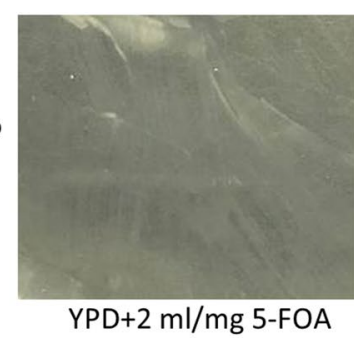

b

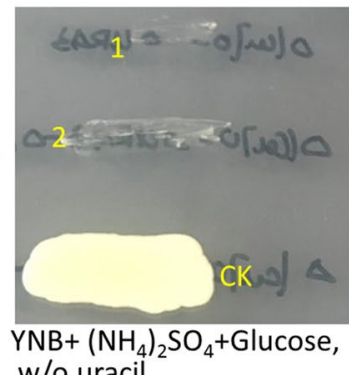
w/o uracil

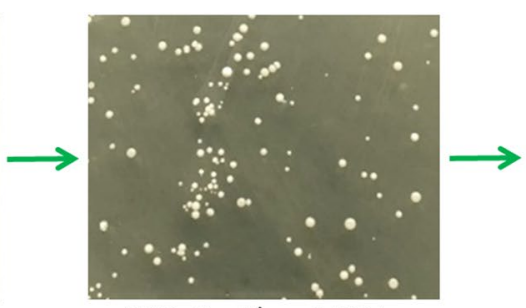

YPD+2 ml/mg 5-FOA

C

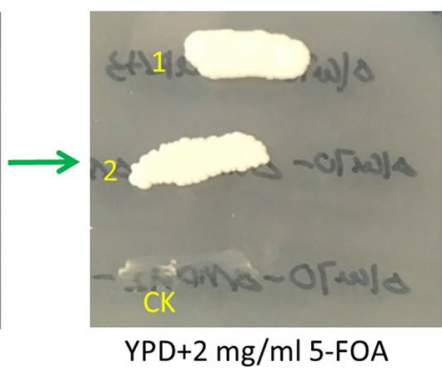

g

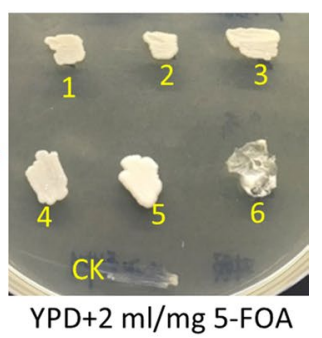

d

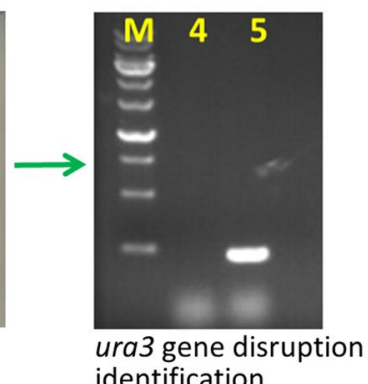

h

Fig. 1 The schematic flow to obtain authentic URA3 disruption mutant. The $1.2 \mathrm{~kb}$ upstream (lane 1, a) and downstream (lane 2, a) of the ura3 gene was amplified separately, then the 2.4-kb fragment (lane 3, a) was obtained by fusion PCR to merge $1.2 \mathrm{~kb}$ up and downstream. Then the $2.4-\mathrm{kb}$ fragment was transformed into HCY109 (ery929 $\triangle$ Ku70), plated on YPDF medium (10 g/L yeast extract, $5 \mathrm{~g} / \mathrm{L}$ tryptone, $10 \mathrm{~g} / \mathrm{L} \mathrm{glucose,} 2 \mathrm{mg} / \mathrm{ml}$ 5-FOA, $15 \mathrm{~g} / \mathrm{L}$ agar powder, $\mathrm{pH}$ 6.5) and cultivated at $30^{\circ} \mathrm{C}$ for 5 days (b). Colonies were grown (c) and transferred to a new YPDF plate cultivated at $30^{\circ} \mathrm{C}$ for 5 days (d). Then the colonies were transferred to synthetic complex medium without uracil (SC-U, $10 \mathrm{~g} / \mathrm{L}$ yeast nitrogen base, $5 \mathrm{~g} / \mathrm{L}$ ammonia sulfate, $10 \mathrm{~g} / \mathrm{L}$ glucose, without uracil) (e). If the ura3 gene was authentically disrupted, the mutants cannot grow on the SC-U medium $(1,2,3$ in $\mathbf{e})$, or they are not authentic ura3 gene disruption $(4,5,6$ in $\mathbf{e})$. Then two putative ura3-deficient mutants were streaked on SC- $U$ plate $(\mathbf{f})$ and YPDF plate (g), they showed opposite growth. A ura3-deficient mutant was further to be identified by PCR to amplify the 480-bp fragment in ura3 gene, and no 480-bp fragment can be amplified (lane 4 in $\mathbf{h}$ ), but the 480-bp fragment can be amplified for the control strain (HCY109, ery929 $\Delta$ Ku 70) (lane 5 in $\mathbf{h}$ ). The No. 1 colony in $\mathbf{g}$ designated as HCY109-2 was used as the host to conduct metabolic engineering 
Scheffersomyces stipitis CBS6054 encoding mannitol dehydrogenase (MDH)-like, classical (c) SDRs (shortchain dehydrogenases/reductases) did not lead to the identification of additional candidate genes. To identify arabitol dehydrogenase encoding gene, the D-arabinitol 2-dehydrogenase gene from Scheffersomyces stipitis CBS6054 (XP_001385035) and Wallemia ichthyophaga (XM_009272203) was used as a query to blast the genome of $Y$. lipolytica CGMCC7326. Gene g1595.t1 (YALIOF02211g) was found with $54.73 \%$ identity to gene XP_001385035 while gene g3858.t1 (YALIOE05643g) showed $54.9 \%$ identity to gene XM_009272203. The identity of g1595.t1 and g3858.t1 genes is $44.39 \%$.

Rodriguez et al. [25] revealed the xylose utilization pathway in $Y$. lipolytica and found the gene YALIOE12463g (GenBank no. XM_503864) has xylitol dehydrogenase (XDH) with NAD as a cofactor in vitro, when expressed in E. coli. When overexpressed in Y. lipolytica, Polf along with XKS (xylulose kinase gene) resulted in improved growth on xylitol. However, no other polyol substrates were tested with purified $y l X D H$ in this article, so it is necessary to determine whether the $y l X D H$ has mannitol or D-arabitol dehydrogenase activity and is involved in mannitol or arabitol synthesis or not. The counterpart gene in CGMCC 7326 was g4121.t1, with a $100 \%$ identity to YALIOE $12463 g$.

Therefore, five genes, which encode putative enzymes with mannitol and/or D-arabitol dehydrogenase were identified, namely YlAraDH1 (g1595.t1, YALIOF02211g), YlAraDH2 (g3858.t1, YALIOE05643g), YlMDH1 (g5130. t1, YALIOB16192g), YlMDH2 (g2069.t1, YALIOD18964g), and $Y l X D H$ genes (g4121.t1, YALIOE12463g) for further biochemical characterization.

\section{Characterization of purified YIAraDH1, YIAraDH2, YIMDH1, YIMDH2, YIXDH enzymes}

The YlAraDH1, YlAraDH2, YlMDH1, YlMDH2, YlXDH encoding genes were expressed in $E$. coli, and the corresponding proteins were purified by Ni-NTA chromatography with the purity of above $95 \%$ (Fig. 2). For each purified enzyme, the enzymatic activity, both oxidation, and reduction, was measured for different substrates (Table 2). All enzymes except xylitol dehydrogenase (YlXDH) were able to oxidize mannitol, D-arabitol, xylitol, D-sorbitol. Among these dehydrogenases, YlAraDH1 has the most robust activity towards mannitol, D-arabitol, xylitol, and D-sorbitol, whereas YlMDH1 exhibited the weakest activity toward those four polyols. YlXDH has the strongest xylitol dehydrogenase activity. We also tested other polyols such as ribitol, erythritol, and glycerol as well as primary alcohols (n-butanol, isobutanol, ethanol) as substrates. However, no activities were observed for all five enzymes (data not shown). The purified enzymes were also tested for their ability to reduce substrates such as fructose, L-sorbose, or D-xylulose. As shown in Table 2, all tested enzymes except YlXDH were able to reduce these substrates. For substrates such as ribose, mannose, xylose, glucose, and fructose-6P, no activity could be detected (data not shown). According to Table 2, all enzymes have mannitol dehydrogenase activity, and YlAraDH1, YlAraDH2, YlMDH1, YlMDH2 have D-arabitol dehydrogenase activity. Regarding cofactor specificity, YlAraDH1, YlAraDH2, and YlXDH were defined as $\mathrm{NAD}(\mathrm{H})$-dependent, while YlMDH1, YlMDH2 are strictly NADP(H)-dependent. For YlMDH1, these results are in accordance with Dulermo et al. [23] and Napora et al. [24].

In order to verify if these enzymes are involved in the synthesis of mannitol and D-arabitol from glucose, the corresponding encoding genes were disrupted in $Y$.

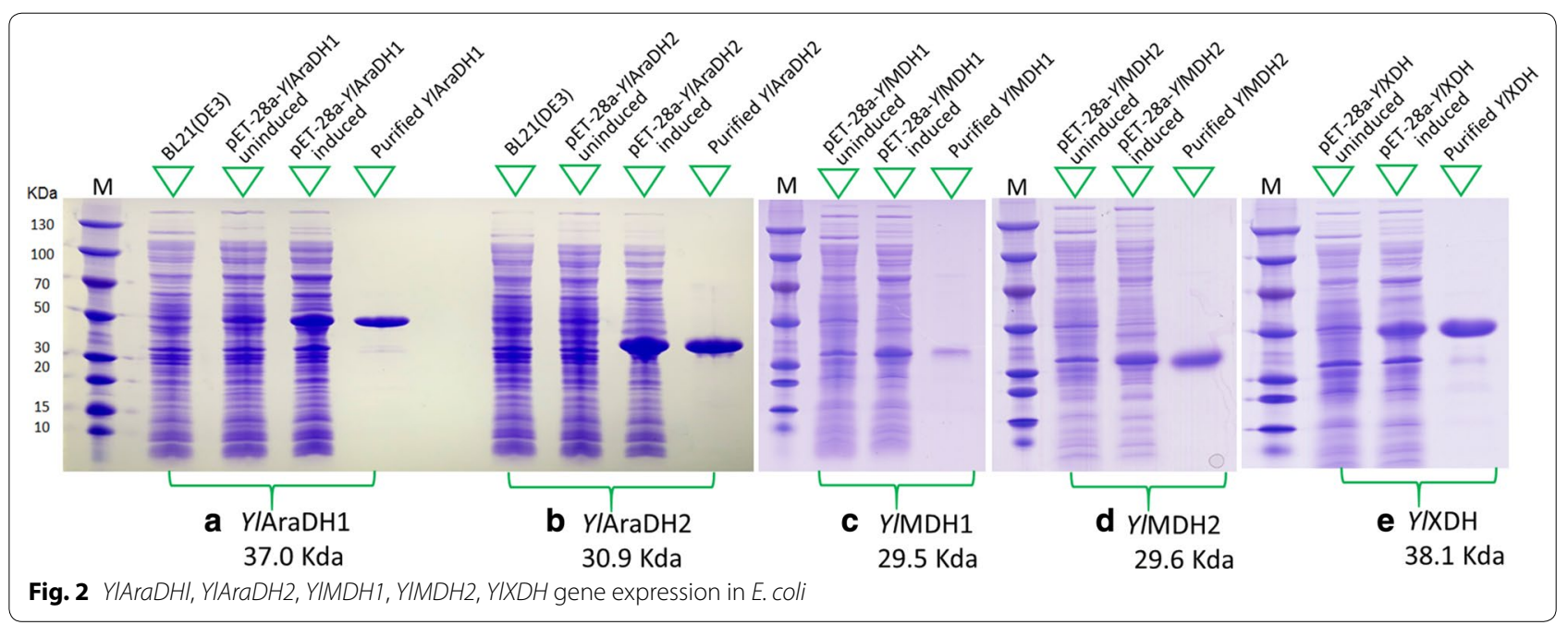


Table 2 Substrates/cofactors specificity of YIAraDH1, YIAraDH2, YIMDH1, YIMDH2, YIXDH

\begin{tabular}{|c|c|c|c|c|c|}
\hline \multirow[t]{2}{*}{ Substrates $\left(\mathrm{pH}^{\mathrm{a}}\right)$} & $\begin{array}{l}\text { YIAraDH1 }{ }^{b} \\
\text { (YALIOF02211p) }\end{array}$ & $\begin{array}{l}\text { YIAraDH2 }^{\mathrm{b}} \\
\text { (YALI0E05643p) }\end{array}$ & $\begin{array}{l}\text { YIMDH1c } \\
\text { (YALIOB16192p) }\end{array}$ & $\begin{array}{l}\text { YIMDH2c } \\
\text { (YALIOD18964p) }\end{array}$ & $\begin{array}{l}\text { YIXDH } \\
\text { (YALI0E12463p) }^{\mathbf{b}}\end{array}$ \\
\hline & Product (activity ${ }^{d}$ ) & Product (activity) & Product (activity) & Product (activity) & Product (activity) \\
\hline Mannitol (pH 8.0) & Fructose (10.3) & Fructose (6.5) & Fructose (2.7) & Fructose (8.4) & Fructose (0.12) \\
\hline D-Arabitol (pH 8.0) & D-Xylulose (5.3) & D-Xylulose (6.3) & D-Xylulose (0.12) & D-Xylulose (0.83) & - \\
\hline Xylitol (pH 8.0) & D-Xylulose (3.6) & D-Xylulose (4.6) & D-Xylulose (0.23) & D-Xylulose (1.4) & D-Xylulose (4.35) \\
\hline D-Sorbitol (pH 8.0) & L-Sorbose (7.5) & L-Sorbose (5.2) & L-Sorbose (0.35) & L-Sorbose (0.86) & Fructose (2.23) \\
\hline Fructose (pH 6.0) & Mannitol (2.6) & Mannitol (1.7) & Mannitol (0.82) & Mannitol (5.6) & Mannitol (0.04) \\
\hline L-Sorbose (pH 6.0) & Sorbitol (2.4) & Sorbitol (2.6) & Sorbitol (0.15) & Sorbitol (0.23) & - \\
\hline D-Xylulose (pH 6.0) & Arabitol (1.4) & Arabitol (2.2) & Arabitol (0.12) & Arabitol (0.54) & Xylitol (2.34) \\
\hline
\end{tabular}

a Reacted at appropriate $\mathrm{pH} .{ }^{\mathrm{b}, \mathrm{c}}$ With $\mathrm{NAD}(\mathrm{H})$ or NADP(H) as cofactor separately. ${ }^{\mathrm{d}} \mathrm{U} / \mathrm{mg}$ protein. "-", undetected activity

lipolytica HCY109. The correctness of the mutant genotype was verified by analytical PCR with primers listed in Table 1. The lack of PCR amplification in mutant strains as compared to the parental strain confirmed the correct gene disruption, namely YlAraDH1, YlAraDH2, $Y l M D H 1, Y l M D H 2$, and $Y l X D H$ (Fig. 3a). The disrupted strains were then grown in a shake flask for $120 \mathrm{~h}$ in the $\mathrm{YPD}_{300}$ medium. As shown in Fig. 3, no significant differences could be observed in both cell growth and polyols synthesis for all the tested disrupted strains as compared to the parental strain (ery929 $\Delta k u 70 \Delta u r a 3$ ), except strain HCY113 disrupted for gene YlMDH2 (YALIOD18964g). For this latter, production of both mannitol and D-arabitol was impaired while erythritol production was slightly improved by $7.9 \%$, reached $177 \pm 3 \mathrm{~g} / \mathrm{L}$ from $164 \pm 3 \mathrm{~g} / \mathrm{L}$ (Fig. 3c-e). The above results demonstrate that mannitol is produced from the enzymatic activity of $Y l M D H 2$ as disruption of YlAraDH1, YlAraDH2, YlMDH1, YlXDH had no effects on mannitol synthesis. This was further evidenced by the synthesis of mannitol in the $\triangle Y l M D H 2$ mutant complemented with the $Y l M D H 2$ gene (data not shown). Finally, it is worth mentioning that although YlMDH1 and YlMDH2 shared $74.8 \%$ similarity in amino acid, they present different catalytic activities.

To explain the discrepancy between the enzymatic activity of the purified enzyme in vitro and the phenotype of disruption mutants, we speculated that genes YlAraDH1, YlAraDH2, YlMDH1, YlXDH were not or poorly expressed in those experimental conditions (i.e., glucose medium). Therefore, gene expressions were quantified during the growth of wild-type strain CGMCC7326 in the $\mathrm{YPD}_{300}$ medium. As shown in Fig. 4, the expression level of gene $\mathrm{YlMDH} 2$ was high as compared to that of genes YlAraDH1, YlAraDH2, YlMDH1, YlXDH.

Dulermo et al. [23] speculated that similarly to other Ascomycetes, two pathways may exist in Y. lipolytica for mannitol synthesis. Different genes with putative mannitol and/or arabitol dehydrogenase activity have been identified, and the corresponding enzymes were purified. Most of them were found able to reduce fructose into mannitol and xylulose into arabitol in vitro. However, mutant disrupted for gene YALIOD18964 (YlMDH2) was the only one unable to produce mannitol from glucose, suggesting that $\mathrm{YlMDH} 2$ is the only active mannitol dehydrogenase inside the cell. This was confirmed by quantification of the gene expression level, which was significantly higher for YALIOD18964 than for the other tested gene. From the substrate specificity, it may be deduced that $\mathrm{YlMDH} 2$ is instead a mannitol dehydrogenase (Mdh) than a mannitol-1P dehydrogenase (Mpd). Indeed, it could not reduce fructose-6P, suggesting thus that it is not involved in an Mpd-Mpp-like pathway.

\section{Disruption of YIEYD1}

Although $Y$. lipolytica can synthesize erythritol in response to osmotic stress, it also has the ability to reconsume it in isotonic conditions. In this catabolic pathway, erythritol is first converted into erythrulose by an erythritol dehydrogenase encoded by gene EYD1 [26]. Therefore, the gene was disrupted in strains HCY109-2 $(\triangle k u 70 \triangle u r a 3)$ and HCY113 ( $\triangle k u 70 \triangle u r a 3 \Delta m d h 2)$. Gene disruption in the chassis strain HCY109-2 yielded an $8 \%$ increase in erythritol titer $(178 \pm 3 \mathrm{~g} / \mathrm{L}$, Fig. $3 \mathrm{C})$ as compared to the parental strain (HCY113). Glucose and erythritol consumption rates were determined during the culture of strains HCY113 $(\triangle k u 70 \triangle u r a 3 \Delta m d h 2)$ and HCY115 ( $\triangle$ ku $70 \triangle$ ura $3 \triangle m d h 2 \Delta$ eyd 1$)$ in a medium containing $20 \mathrm{~g} / \mathrm{L}$ glucose and $20 \mathrm{~g} / \mathrm{L}$ erythritol. As shown in Fig. 5, strain HCY115 was unable to catabolize erythritol while it showed a fivefold increased glucose uptake rate $(0.83 \mathrm{~g} / \mathrm{L} \mathrm{h})$ in the first $12 \mathrm{~h}$ of growth. At the industrial scale, the erythritol production process is operated at high glucose concentration (up to $300 \mathrm{~g} / \mathrm{L}$ ). In these conditions, no erythritol is reconsumed by the cell 


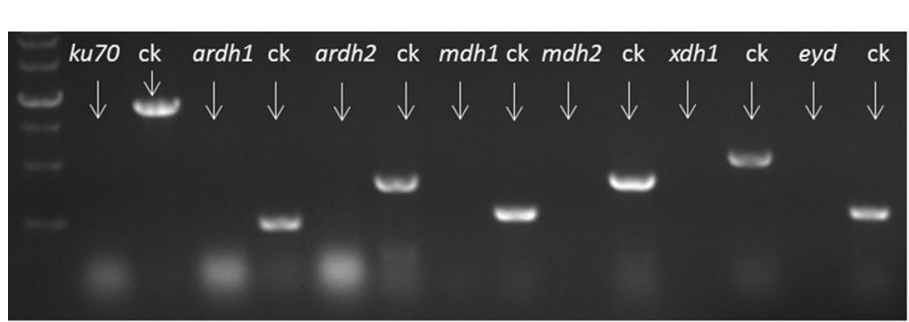

a

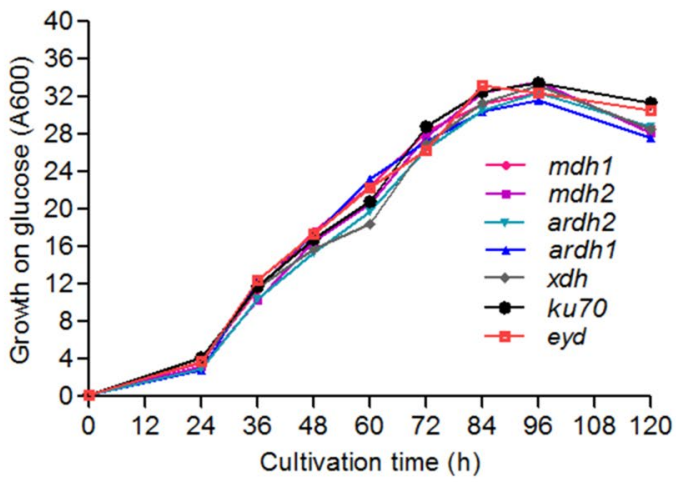

b

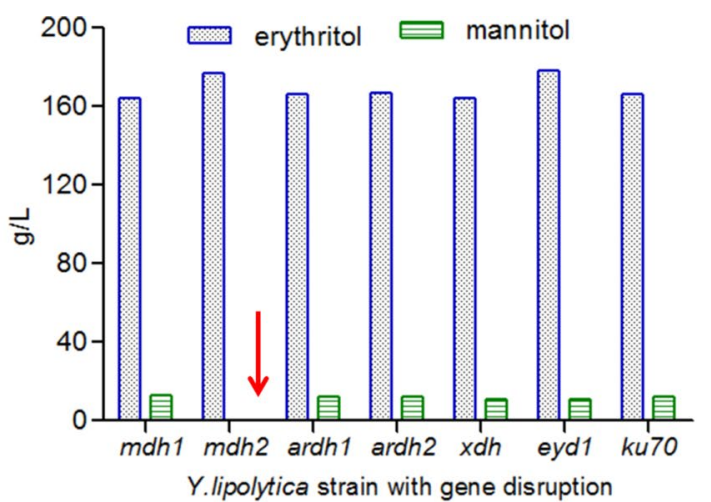

C

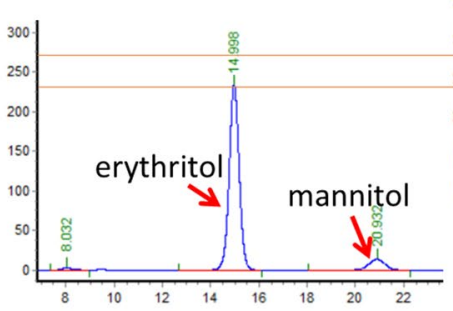

d

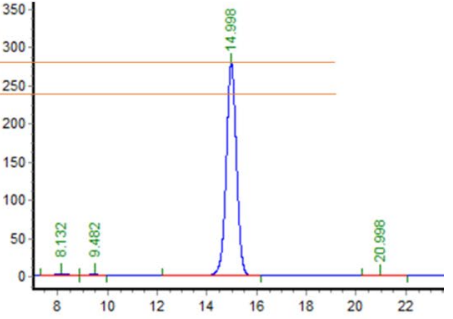

e

Fig. 3 Effects of gene disruption on cell growth, mannitol, and erythritol synthesis. a Molecular identification of 7 genes disruption (Ku70, YIAraDH1, YIAraDH2, YIMDH1, YIMDH2, YIXDH, YIEYD1 genes), no corresponding band can be amplified from the disruptants, but the band can be amplified for wild-type control strain (Y. lipolytica CGMCC7326, ery929), indicating Ku70, YIAraDH1, YIAraDH2, YIMDH1, YIMDH2, YIXDH, or YIEYD1 genes were disrupted individually. b Growth curves of different disruptants on liquid medium containing $300 \mathrm{~g} / \mathrm{L}$ glucose. c Effects of various gene disruption on erythritol and mannitol biosynthesis, only mdh2 gene disruption can result in no mannitol synthesis. $\mathbf{d}$, e The HPLC chromatography of wild-type strain and $m d h 2$ gene disruption, showing no mannitol when the mdh2 gene was disrupted

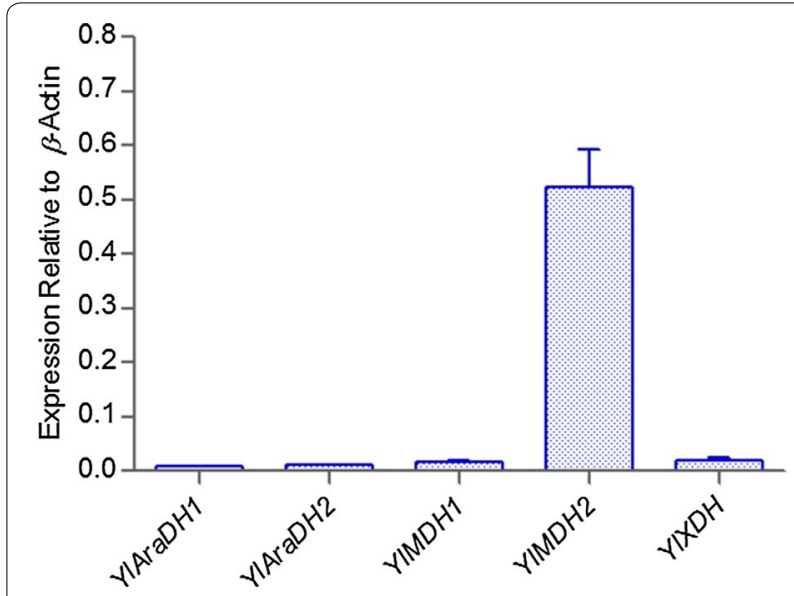

Fig. 4 Comparison of YIAraDH1, YIAraDH2, YIMDH1, YIMDH2, YIXDH expression levels relative to $\beta$-actin. YIAraDH1, YIAraDH2, YIMDH1, YIMDH2, YIXDH gene mRNA quantification of wild-type $Y$. lipolytica (CGMCC7326) grown on $300 \mathrm{~g} / \mathrm{L}$ glucose, mRNA levels are represented as copy number relative to the copy number of $\beta$-actin due to the high osmotic pressure. However, at the end of the production process, glucose must be depleted in the culture medium for ease of erythritol purification. It is known that at low glucose concentration (around $20 \mathrm{~g} / \mathrm{L}$ and below), erythritol starts to be reconsumed by the cell together with the remaining glucose. To avoid this erythritol consumption, the erythritol catabolic pathway could be disrupted. Carly et al. [27] disrupted EYK1 encoding erythrulose kinase, the second enzyme of the pathway. Although this strategy led to mutant strain impaired in erythritol catabolism, the disrupted strain was still able to convert erythritol into erythrulose leading to a mixture of erythritol and erythrulose. To avoid this, we disrupted the first gene of the pathway, EYD1.

\section{Improving thermoresistance by expression of Sc.rsp5 gene in Y. lipolytica}

The optimal growth temperature of $Y$. lipolytica ranges between 28 and $30{ }^{\circ} \mathrm{C}[13,28,29]$, and at higher temperature, cell growth ability decreases drastically. Yeast metabolism could be considered as an exothermic process for instance; glucose catabolism has a specific heat production of $1798 \mathrm{~kJ} / \mathrm{mol}$ [30]. Since Y. lipolytica 

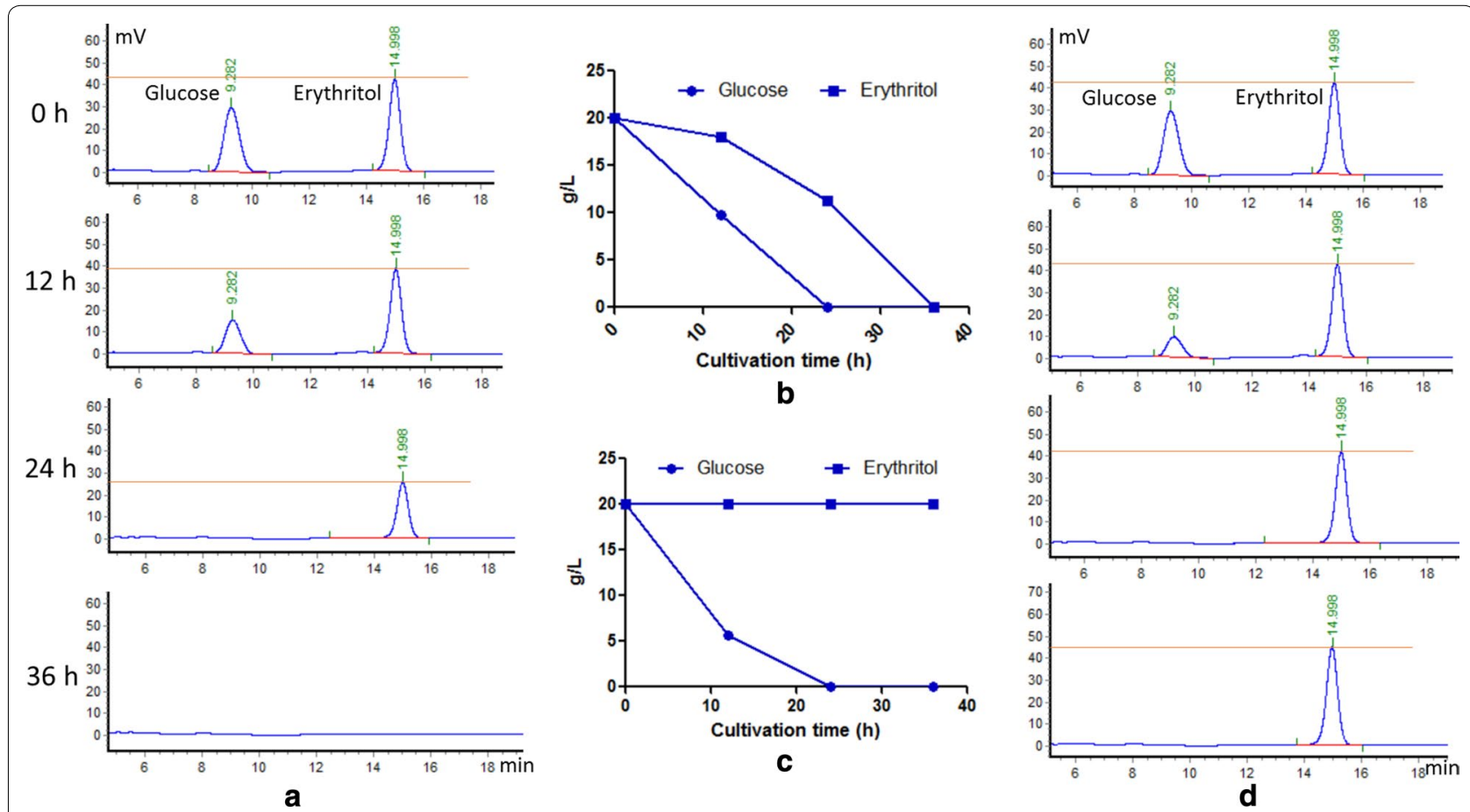

Fig. 5 Effect of disruption of YIEYD1 gene on glucose and erythritol utilization. a HPLC profile of glucose and erythritol utilization by wild-type strain harboring the EYD1 gene. $\mathbf{b}$ Glucose and erythritol utilization rate by wild-type strain harboring the EYD1 gene. c Glucose and erythritol utilization rate by the EYD1 gene disruption strain. $\mathbf{d}$ HPLC profile of glucose and erythritol utilization by the EYD1 gene disruption strain

is known to be able to grow at high cell density and to sustain high glucose concentration, the energy, and thus the cost, requested for bioreactor cooling is to take into account, especially at industrial scale. Therefore, increasing the thermotolerance of strain HCY115

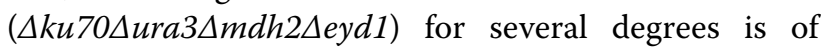
interest to develop an efficient erythritol production process. Several strategies have been used for that purpose in yeast, such as overexpression of heat shock proteins (HSP) or transcription factors [31-34]. In Saccharomyces cerevisiae, overexpression of gene RSP5 encoding ubiquitin ligase allowed the cell to grow up to $41{ }^{\circ} \mathrm{C}$ [35]. Therefore, the $S$. cerevisiae RSP5 gene was expressed in strain HCY115 ( $\Delta k u 70 \Delta u r a 3 \Delta m d h 2 \Delta e y d)$ to yield strain (HCY117, $\Delta k u 70 \Delta u r a 3 \Delta m d h 2 \Delta e y d-p h p 4 d-r s p 5$, php4d hereinafter is $h p 4 d$ promoter). The HCY117 strain can grow well at $34{ }^{\circ} \mathrm{C}$ (Fig. 6) and efficiently produce erythritol at $33^{\circ} \mathrm{C}$.

Transform Y. lipolytica HCY115 with Sc.rsp5 gene expression cassette (pINA1313-Sc.rsp5, cut with NotI) were spread on YPD plate and allowed to cultivate at $34{ }^{\circ} \mathrm{C}$. Colonies can grow at $34{ }^{\circ} \mathrm{C} 7$ days later (Fig. 6a). Then one colony grew at $34{ }^{\circ} \mathrm{C}$ from the plate (Fig. 6a), and the control strain (HCY115, without Sc.rsp5 gene) were picked up, cultivated on new plates at $34{ }^{\circ} \mathrm{C}$. The control strain grew poorly at $34{ }^{\circ} \mathrm{C}$ (Fig. $6 \mathrm{~b}$ ), but the
HCY117 strain can boost well (Fig. 6c). When grown in a liquid medium, the growth is the same as that on solid plate medium (data not shown). The control strain HCY115 grows poorly at $34{ }^{\circ} \mathrm{C}$, but $\mathrm{HCY} 117$ can grow well with a cell density of $24.4 \pm 2.2$ at $45 \mathrm{~h}$ (Fig. 6d). To investigate the thermoresistance, the control strain HCY115 and Sc.rsp5 harboring strain HCY117 were heat-shocked at $45^{\circ} \mathrm{C}$ for $60 \mathrm{~min}$, then diluted by tenfold and cultivated on the YPD plate at $30{ }^{\circ} \mathrm{C}$ for $48 \mathrm{~h}$. The $\mathrm{Sc}$. rsp5 harboring strain HCY117 can grow well after heatshocked at $45^{\circ} \mathrm{C}$ for $60 \mathrm{~min}$ (Fig. 6e, 1), whereas the control strain HCY115 grows poorly (Fig. 6e, 2).

In order to evaluate whether the Sc.rsp5 gene in HCY117 was induced under higher temperature, the cells of Sc.rsp 5 harboring strain HCY117 was heat treated at $30,33,36,39$, and $42{ }^{\circ} \mathrm{C}$ for $4 \mathrm{~h}$, and total RNA were extracted. Sc.rsp 5 mRNA quantification indicates that the $S c . r s p 5$ gene can be induced at a higher temperature, the mRNA level is two to threefold than that of at $30{ }^{\circ} \mathrm{C}$ (Fig. 6f).

HCY 117 ( $\Delta k u 70 \Delta m d h 2 \Delta e y d-p h p 4 d-r s p 5)$ can produce more erythritol at $300 \mathrm{~g} / \mathrm{L}$ glucose at $33{ }^{\circ} \mathrm{C}$ than that of HCY115 ( $\Delta k u 70 \Delta u r a 3 \Delta m d h 2 \Delta e y d$ ), with $175 \pm 5 \mathrm{~g} / \mathrm{L}$ erythritol in $96 \mathrm{~h}$ via $154 \pm 5 \mathrm{~g} / \mathrm{L}$ in $120 \mathrm{~h}$ at $33{ }^{\circ} \mathrm{C}$ (Fig. 6g), indicating that harboring rsp5 gene of S. cerevisiae renders thermoresistance for Y. lipolytica. 


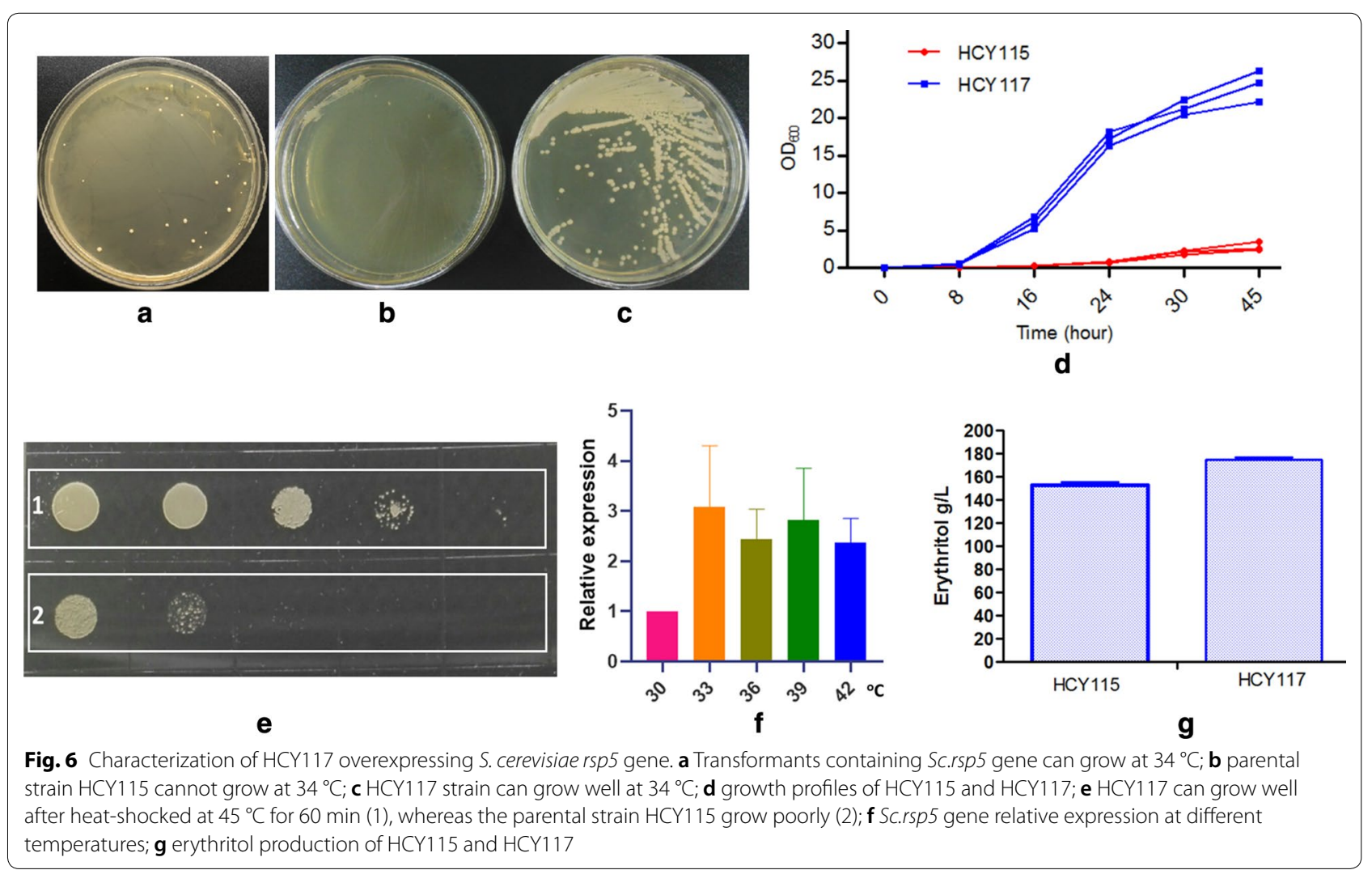

As to the acidic and alkaline conditions are the stress factors for $Y$. lipolytica, heat shock was also the stress factor for $Y$. lipolytica, which may cause an increase in antioxidant protection [36, 37]. This process cannot be prevented by adaptive induction of the enzymes responsible for antioxidant protection under high temperature, which results in cell damage and decreases survival rate and causes the decreased enzyme activities involved in PPP, which is responsible for erythritol synthesis. A quick method for estimating the percentage of viable cells in a yeast population is to use alkaline methylene blue staining, which is very simple and highly sensitive [38]. When cells were stained with alkaline methylene blue solution with a pH of 10.6 at $25{ }^{\circ} \mathrm{C}$ for $5 \mathrm{~min}$, the percentage of unstained cells was consistent with viability measurements made using the slide culture method. Using this method, the cell viability or survival rate of $\mathrm{HCY} 117$ at $34{ }^{\circ} \mathrm{C}$ and $35^{\circ} \mathrm{C}$ is lower than that of at $33^{\circ} \mathrm{C}$ and $30{ }^{\circ} \mathrm{C}$. At $30-33{ }^{\circ} \mathrm{C}$, the stained blue cells (low or no viability cells) account for $5-7 \%$ of total cells (Fig. $7 \mathrm{a}, \mathrm{b}$ ), while at $34{ }^{\circ} \mathrm{C}$ and $35^{\circ} \mathrm{C}$, the ratio increased to $35 \%$ and $50 \%$ (Fig. 7c, d). The transketolase activity at $30{ }^{\circ} \mathrm{C}, 33^{\circ} \mathrm{C}, 34{ }^{\circ} \mathrm{C}$ and $35^{\circ} \mathrm{C}$ was $0.69 \pm 0.12,0.67 \pm 0.06,0.43 \pm 0.05$, and $0.28 \pm 0.04$ $\mathrm{U} / \mathrm{mg}$ total crude protein, respectively (Fig. 7e), indicating that the higher temperature can impair transketolase activity thus lead to less erythritol synthesis from glucose
(Table 3). Under stress conditions such as at higher temperature, both reactive oxygen species (ROS) generation and the contribution of antioxidant components to the cell viability is higher. It was shown that mannitol plays the role of a potent scavenger of hydroxyl radicals (HO.) and ROS both in vitro and in vivo $[36,37,39]$. The involvement of mannitol in antioxidant protection of fungal cells was also revealed in S. cerevisiae [40]. As for the HCY117 strain, from which no mannitol was synthesized again since the $Y l M D H 2$ gene was disrupted, the cell viability may be lower under stress conditions such as at higher temperatures, for example, at above $33{ }^{\circ} \mathrm{C}$, though the Sc.rsp5 gene can be well expressed.

\section{Improve the NADPH supply in the strain $\mathrm{HCY} 118$ and erythritol production}

As described by Cheng et al. [13], the reduction of erythrose by erythrose reductases needs NADPH as a cofactor. Therefore, regenerating this cofactor from NADP is a key factor in increasing erythritol productivity in strain HCY117. The first reaction of the phosphate pentose pathway (PPP) pathway, catalyzed by the glucose-6P dehydrogenase (G6PD or ZWF), generates NADPH from glucose-6P and $\mathrm{NADP}^{+}$. In yeast, it has been suggested that G6PD has a major role in NADPH production [41]. The 6-phosphogluconate dehydrogenase (GND), which 


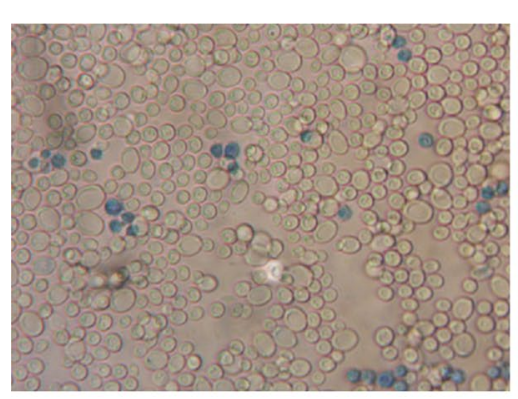

a

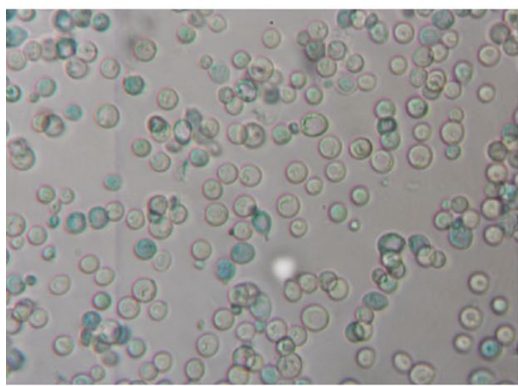

C

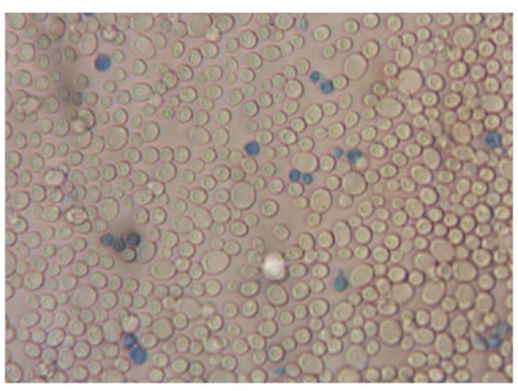

b

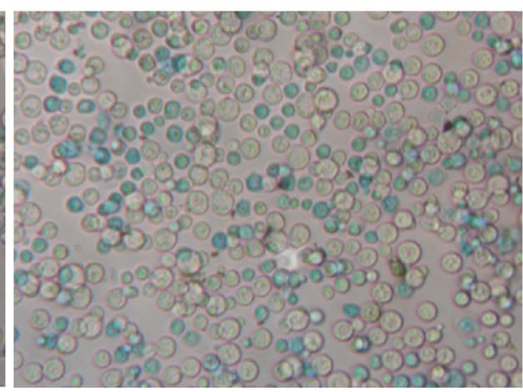

d

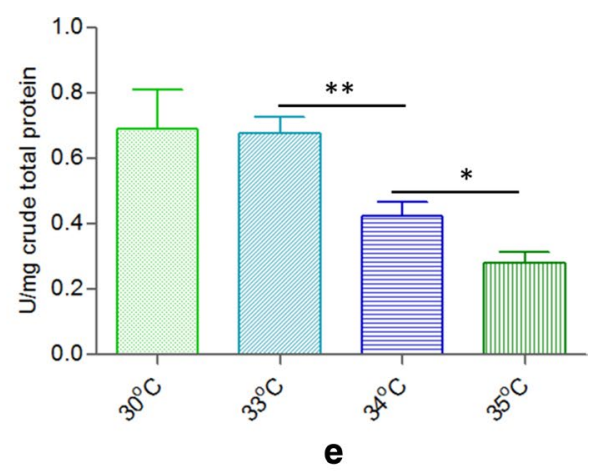

Fig. 7 Cell viability and TKL1 activity of HCY 118 at different temperatures. a Cell viability stain at $30^{\circ} \mathrm{C} ; \mathbf{b}$ : at $33^{\circ} \mathrm{C} ; \mathbf{c}$ : at $34^{\circ} \mathrm{C} ;$ d: at $35^{\circ} \mathrm{C} ; \mathrm{E}: \mathrm{TKL} 1$ activity at $30,33,34$ and $35^{\circ} \mathrm{C}$. Blue stained cells indicated that these cells have low or no viability

Table 3 Summary of fermentation profiles of engineered strain HCY118 and wild-type control strain at $30,33,34,35{ }^{\circ} \mathrm{C}$

\begin{tabular}{|c|c|c|c|c|c|c|c|c|c|c|}
\hline Strains & Temp & $\begin{array}{l}\text { Erythritol } \\
\text { (titer: g/L) }\end{array}$ & $\begin{array}{l}\text { Mannitol } \\
\text { (titer: g/L) }\end{array}$ & $Q_{\text {ery }}(g / L h)$ & $\begin{array}{l}Y_{\text {ery }}(g / g \\
\text { glucose) }\end{array}$ & $T(h)$ & $R_{\text {glu }}(g / L h)$ & $O D_{600}$ & $\mathrm{DCW}(\mathrm{g} / \mathrm{L})$ & $\begin{array}{l}C P_{\text {ery }}(g / g \\
\text { dcw } h)\end{array}$ \\
\hline \multirow{2}{*}{$\begin{array}{l}\text { CGMCC7326 } \\
\text { (wild-type control) }\end{array}$} & $30^{\circ} \mathrm{C}$ & $166 \pm 5.5$ & $7.5 \pm 0.5$ & 1.73 & 0.55 & 96 & 3.13 & $32.4 \pm 1.5$ & 8.1 & 0.22 \\
\hline & $33^{\circ} \mathrm{C}$ & $145 \pm 5.5$ & $12.4 \pm 0.5$ & 1.21 & 0.48 & 120 & 2.5 & $28.8 \pm 1.5$ & 7.2 & 0.17 \\
\hline \multirow[t]{4}{*}{ HCY118 } & $30^{\circ} \mathrm{C}$ & $189 \pm 6$ & 0 & 1.97 & 0.63 & 96 & 3.13 & $30.5 \pm 1.5$ & 7.6 & 0.26 \\
\hline & $33^{\circ} \mathrm{C}$ & $190 \pm 6$ & 0 & 1.97 & 0.63 & 96 & 3.13 & $32.6 \pm 1.5$ & 8.2 & 0.24 \\
\hline & $34^{\circ} \mathrm{C}$ & $162 \pm 5.5$ & 0 & 1.2 & 0.54 & 135 & 2.22 & $24.4 \pm 1.5$ & 6.1 & 0.16 \\
\hline & $35^{\circ} \mathrm{C}$ & $132 \pm 4$ & 0 & 0.78 & 0.44 & 170 & 1.76 & $20.6 \pm 1.5$ & 5.3 & 0.11 \\
\hline
\end{tabular}

$\mathrm{Q}_{\text {ery: }}$ : productivity; $\mathrm{Y}_{\text {ery: }}$ erythritol yield; $\mathrm{R}_{\text {glu: }}$ glucose consumption rate; $\mathrm{DCW}$ : dry cell weight; $\mathrm{CP}_{\text {ery }}$ : cell production rate

catalyzes the third reaction of the PPP pathway, also generates NADPH using 6-phosphogluconate as a substrate. In $Y$. lipolytica, these two enzymes are encoded by gene ZWF1 (YALIOE22649g) and GND1 (YALIOB15598g), respectively [42]. Therefore, overexpressing these two genes in the strain HCY117 ( $\Delta k u 70 \Delta u r a 3 \Delta m d h 2 \Delta e y d-$ php4d-rsp5) will regenerate the NADPH consumed by D-erythrose reductase. Moreover, the flux of carbon (glucose-6P from glycolysis) will be redirected toward the PPP pathway and produce more D-erythrose, the intermediate of erythritol. Therefore, the ZWF1 and GND1 were constitutively expressed in strain HCY117 by transforming expression cassette $26 S$ rDNA-zwf1-hph-gnd1$26 S$ rDNA (sequence 9 in Additional file 1) into HCY117
( $\Delta k u 70 \Delta m d h 2 \Delta e y d:: r s p 5)$, yielding the strain HCY118 ( $\Delta k u 70 \Delta m d h 2 \Delta$ eyd::rsp5::zwf1::gnd1).

Then the erythritol production capacity of the engineered strain HCY118 was evaluated during shakeflask culture at $30,33,34$, and $35{ }^{\circ} \mathrm{C}$, and compared to that of the wild-type strain CGMCC7326. At $30{ }^{\circ} \mathrm{C}$, strain CGMCC7326 produced erythritol with a titer of $166 \pm 5.6 \mathrm{~g} / \mathrm{L}$ erythritol, yield, and productivity of $0.55 \mathrm{~g}$ erythritol/g glucose and $1.73 \mathrm{~g} / \mathrm{L} \mathrm{h}$, respectively (Fig. 8a, b, Table 3). By contrast, for HCY118 erythritol titer, yield and productivity were equal to $189 \pm 6 \mathrm{~g} / \mathrm{L}$, $0.63 \mathrm{~g}$ erythritol/g glucose, and $1.97 \mathrm{~g} / \mathrm{L} \mathrm{h}$, respectively (Fig. 8a, c, Table 3). This represents an increase of $13.8 \%, 14.5 \%$, and $13.9 \%$ for production titer, yield, and 
productivity, respectively, as compared to the control strain CGMCC7326. No significant differences were observed for cell growth and glucose consumption rate between $\mathrm{HCY} 118$ and parental strain at $30{ }^{\circ} \mathrm{C}$ (Table 3). However, for that latter, erythritol content decreased from 166 to $155 \mathrm{~g} / \mathrm{L}$ after $120 \mathrm{~h}$. This was not the case for strain HCY118, which is unable to reconsume erythritol even after $120 \mathrm{~h}$ of culture (Fig. 8a). Furthermore, HCY118 did not produce mannitol (Fig. 8c), while the control produces $7.5 \mathrm{~g} / \mathrm{L}$ byproduct mannitol (Fig. 8a, b, and Table 3).

At $33{ }^{\circ} \mathrm{C}$, for $\mathrm{HCY} 118$, the production, yield, productivity, cell biomass, glucose consumption rate, cell production rate, and fermentation time were almost the same to those at $30{ }^{\circ} \mathrm{C}$ (Fig. 8d, f, Table 3). But for the control strain CGMCC7326, the production, yield, productivity, cell biomass, glucose consumption rate, the cell production rate was decreased compared to those at $30{ }^{\circ} \mathrm{C}$, and mannitol amount and fermentation time increased (Fig. 8d, e, Table 3). The production titer, yield, productivity, and cell production rate for HCY118 was improved by $31 \%, 31.3 \%, 62.8 \%, 41.15 \%$, respectively, as compared to that of strain CGMCC7326 at $33^{\circ} \mathrm{C}$.

Since the production remarkably decreased for the control strain at $33{ }^{\circ} \mathrm{C}$, we did not conduct the fermentation process above $33{ }^{\circ} \mathrm{C}$ for the strain CGMCC7326. Then the erythritol fermentation was conducted only for $\mathrm{HCY} 118$ at 34 and $35{ }^{\circ} \mathrm{C}$ to evaluate whether it retains

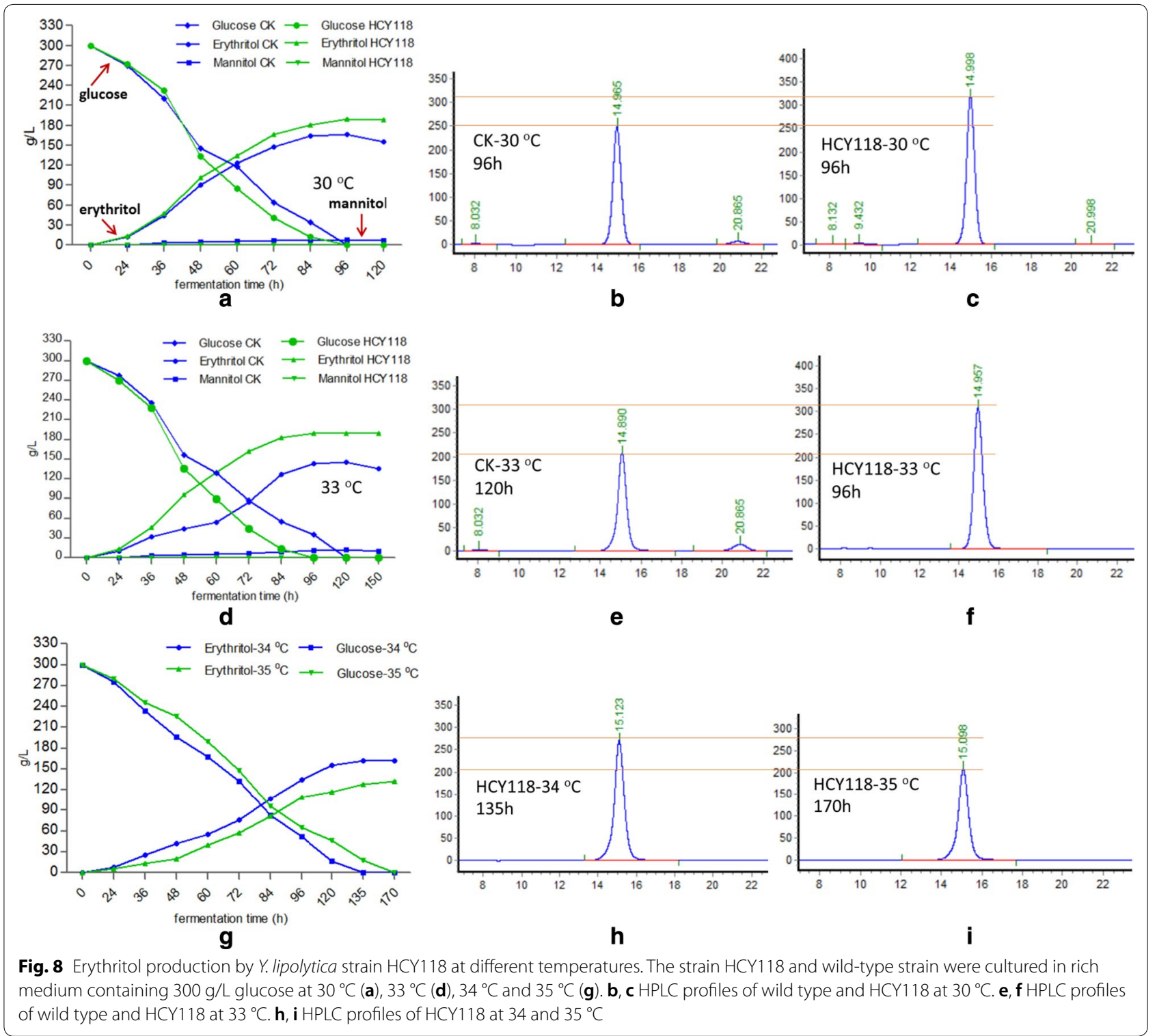


the high production or not above $33{ }^{\circ} \mathrm{C}$. Results indicated that the production, yield, productivity, cell biomass, cell production rate, and glucose consumption were decreased at 34 and $35{ }^{\circ} \mathrm{C}$ when the fermentation time increased to 135 and $170 \mathrm{~h}$ at 34 and $35^{\circ} \mathrm{C}$ for $\mathrm{HCY} 118$

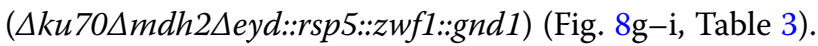
At $34{ }^{\circ} \mathrm{C} / 35{ }^{\circ} \mathrm{C}$, the production, yield, productivity, and cell production rate were reduced by $14.7 \% / 30.5 \%$, $14.3 \% / 30.2 \%, 39.1 \% / 60.4 \%, 29.2 \% / 50 \%$ than those of at $33^{\circ} \mathrm{C}$, respectively. Though strain $\mathrm{HCY} 118$ can grow well at $34{ }^{\circ} \mathrm{C}$ and $35{ }^{\circ} \mathrm{C}$ with a high cell density of 24.4 and 20.6 after 135 and $170 \mathrm{~h}$ fermentation, respectively, its production, yield, productivity, and cell production rate decreased sharply with increasing temperature (Table 3 ), even though from 33 increased to $34{ }^{\circ} \mathrm{C}$, only $1{ }^{\circ} \mathrm{C}$ degree was improved, indicating that erythritol synthesis is very sensitive to high temperature. Therefore, $33{ }^{\circ} \mathrm{C}$ was the temperature limit at which the $\mathrm{HCY} 118$ strain can retain the maximum erythritol production.

To verify the results achieving from 2-L baffled flasks, the pilot and large-scale industrial experiments were conducted separately in $150-\mathrm{L}$ and 30 -cubic meter fermentors containing $300 \pm 10 \mathrm{~g} / \mathrm{L}$ glucose at $33{ }^{\circ} \mathrm{C}$, compared to that of wild-type strain CGMCC7326. The results are shown in Table 4 . After $85 \pm 2 \mathrm{~h}$ fermentation, HCY118 production reached $188 \pm 5 \mathrm{~g} / \mathrm{L}$ erythritol, with yield and productivity of $0.617 \mathrm{~g}$ erythritol/g glucose and $2.18 \mathrm{~g} / \mathrm{L} \mathrm{h}$ in a $150-\mathrm{L}$ fermentor, slightly higher than that of in 2-L baffled flasks $(1.97 \mathrm{~g} / \mathrm{L} \mathrm{h})$. Interestingly, in 30-cubic meter fermentors the fermentation time was reduced to $78 \pm 2 \mathrm{~h}$, the erythritol titer increased to $196 \pm 2 \mathrm{~g} / \mathrm{L}$, with a yield and productivity of $0.653 \mathrm{~g}$ erythritol/g glucose and $2.51 \mathrm{~g} / \mathrm{L} \mathrm{h}$, much higher than that in 2-L baffled flasks. The higher titer, yield, and productivity obtained in $150-\mathrm{L}$ and 30-cubic meter fermenters might be due to better aeration since erythritol synthesis in Y. lipolytica is a process of strictly aerobic respiration, and oxygen supply has a huge impact on erythritol synthesis by $Y$. lipolytica. Oxygen concentration has an effect not only on the mitochondrial electron transport chain, but also on the cytochrome content in cells, which determines the level of energy supply for various metabolic processes, including erythritol and citric acid synthesis in Y. lipolytica [42-44].

\section{Conclusions}

In summary, we first identified five putative genes encoding enzymes that have mannitol/ D-arabitol activity in Y. lipolytica and found only when disruption of $Y l M D H 2$ can result in no byproduct synthesis. By disruption of the $Y l M D H 2$ and $Y l E Y D$ genes, the strain lost its ability to synthesize mannitol, resulting in no byproduct and easy to purify erythritol from the fermentation medium. It cannot utilize erythritol again, leading to an increase in erythritol titer. Then $S c$. $r s p 5$, zwf1, and gnd 1 genes were expressed in acquiring the thermoresistance to grow up to $35{ }^{\circ} \mathrm{C}$ and synthesize maximum erythritol production at $33{ }^{\circ} \mathrm{C}$, $3{ }^{\circ} \mathrm{C}$ higher than that of control strain, which would reduce the cooling cost. Combining such factors, the production, yield, productivity, and cell production rate for HCY118 was improved by $31 \%, 31.3 \%, 62.8 \%$, and $41.15 \%$, respectively, compared to control strain CGMCC7326 at $33{ }^{\circ} \mathrm{C}$. The yield, production, and productivity reached $0.63 \mathrm{~g} / \mathrm{g}, 190 \mathrm{~g} / \mathrm{L}$, and $1.97 \mathrm{~g} / \mathrm{L} \cdot \mathrm{h}$ in 2-L flasks and increased to $0.65,196 \mathrm{~g} / \mathrm{L}$, and $2.51 \mathrm{~g} / \mathrm{L} \mathrm{h}$ in $30-\mathrm{m}^{3}$ fermentor, respectively, which has economically practical importance.

\section{Future perspectives}

Erythritol was mainly synthesized from glucose via PPP, which includes oxidative and non-oxidative pathways. The oxidative pathway regenerates two molecular NADPH by the successive oxidation process, and one carbon atom of 6-phosphate gluconate was released as $\mathrm{CO}_{2}$. The 6-phosphate gluconate was converted to 5-phosphate ribulose, which was fluxed into a non-oxidative pathway, and finally converted into D-erythrose, which then reduced to erythritol by NADPH-dependent erythrose reductases (ERs). Based on the oxidative and non-oxidative pathways, the highest erythritol production reported so far is hard to exceed $200 \mathrm{~g} / \mathrm{L}$ erythritol from $300 \mathrm{~g} / \mathrm{L}$ glucose; at least 100 glucose was exhausted

Table 4 The fermentation profiles of engineered strain $\mathrm{HCY} 118$ at $33^{\circ} \mathrm{C}$ in $150-\mathrm{L}$ and 30 -cubic meter fermentors

\begin{tabular}{|c|c|c|c|c|c|c|c|c|c|c|}
\hline Strains & $\begin{array}{l}\text { Fermentor } \\
\text { volume }\end{array}$ & $\begin{array}{l}\text { Erythritol } \\
\text { (g/L) }\end{array}$ & $\begin{array}{l}\text { Mannitol } \\
\text { (g/L) }\end{array}$ & $\begin{array}{l}Q_{\text {ery }} \\
\text { (g/L h) }\end{array}$ & $\begin{array}{l}Y_{\text {ery }}(g / g \\
\text { glucose) }\end{array}$ & $\mathrm{T}$ (hour) & $\begin{array}{l}R_{\text {glu }} \\
\text { (g/L h) }\end{array}$ & $O D_{600}$ & $\mathrm{DCW}(\mathrm{g} / \mathrm{L})$ & $\begin{array}{l}C P_{\text {ery }}(g / g \\
\text { dcw } h)\end{array}$ \\
\hline \multirow{2}{*}{$\begin{array}{l}\text { CGMCC7326 } \\
\text { (wild type) }\end{array}$} & $150 \mathrm{~L}$ & $156 \pm 5$ & $6.8 \pm 0.5$ & 1.3 & 0.52 & 120 & 2.5 & $27.6 \pm 1.5$ & 6.9 & 0.19 \\
\hline & $30 \mathrm{~m}^{3}$ & $165 \pm 5$ & $7.2 \pm 0.5$ & 1.57 & 0.55 & 105 & 2.86 & $31.8 \pm 1.5$ & 8.0 & 0.20 \\
\hline \multirow[t]{2}{*}{ HCY118 } & $150 \mathrm{~L}$ & $188 \pm 5$ & 0 & 2.21 & 0.627 & $85 \pm 2$ & 3.53 & $34.5 \pm 1.5$ & 8.6 & 0.26 \\
\hline & $30 \mathrm{~m}^{3}$ & $196 \pm 2$ & 0 & 2.51 & 0.653 & $78 \pm 2$ & 3.85 & $36.8 \pm 1.5$ & 9.2 & 0.27 \\
\hline
\end{tabular}

$\mathrm{Q}_{\text {ery }}$ : productivity; $\mathrm{Y}_{\text {ery }}$ : erythritol yield; $\mathrm{R}_{\text {glu: }}$ glucose consumption rate; $\mathrm{DCW}$ : dry cell weight; $\mathrm{CP}_{\text {ery }}$ : cell production rate 
via aerobic respiration to produce biomass, citric acid, and $\mathrm{CO}_{2}$. However, cell biomass (DCW) produced was not more than $9 \mathrm{~g} / \mathrm{L}$ (this study), and citric acid was less than $12 \mathrm{~g} / \mathrm{L}$ [13], so about $80 \mathrm{~g} / \mathrm{L}$ glucose was exhausted to produce $\mathrm{CO}_{2}$, part of which was produced by oxidative PPP. Therefore, downregulating the oxidative PPP would provide another strategy to further increase erythritol production from glucose by which more glucose was channeled into non-oxidative pathway by transketolase, which converts glycolysis intermediates 6-phosphate fructose and 3-phosphate glyceraldehyde to 5-phosphate xylulose and 4-phosphate erythrose, which then convert to D-erythrose by dephosphorylation, then reduced to erythritol by strict NADPH-dependent ERs. Strict NADPH-dependent ERs can be modified to be both $\mathrm{NADH}$ and NADPH-preferred by protein engineering. Through the non-oxidative pathway and ERs cofactor engineering, the carbon atom economy of glucose can be improved, and erythritol production and yield are further enhanced. As an alternative, the phosphoketolase gene, which catalyzes 6-P fructose to 4-P erythrose and acetyl-P (AcP) could be introduced into Y. lipolytica to increase the amount of intermediate 4-P erythrose [45], to increase erythritol production. The chart of erythritol synthesis from the non-oxidative pathway is illustrated in Fig. 9. This research is being undertaken in our group.

\section{Materials and methods}

\section{Chemicals and biological reagents}

D-mannitol, D-sorbitol, D-arabitol, xylitol, ribitol, erythritol, glycerol, D-fructose-6-P, and D-fructose were obtained from Sigma-Aldrich (St. Louis, United States). Coomassie brilliant blue R-250, cofactors NADP, NAD, $\mathrm{NADH}, \mathrm{NADPH}$, and antibiotics were purchased from Sangon Biotech (Shanghai, China). New England Biolabs or Takara supplied all restriction enzymes. Highfidelity KOD-Fx, $2 \times$ ready-to-use qTaq mixture for PCR were purchased from Toyobo (Japan). RNA extraction kit, reverse transcription kit, and qPCR kit were obtained from Vazyme Biotech Co., Ltd (Nanjing, China). All other chemicals were of analytical grade.

\section{Strains, media, and culture conditions}

The Escherichia coli and Y. lipolytica strains used in this study are listed in Table 1 . The E. coli strains were grown at $37{ }^{\circ} \mathrm{C}$ in Luria-Bertani (LB) medium supplemented with ampicillin $(100 \mathrm{mg} / \mathrm{L})$ or kanamycin sulfate $(50 \mathrm{mg} / \mathrm{L})$. The $Y$. lipolytica strains were grown at $30{ }^{\circ} \mathrm{C}$ in YPD $(10 \mathrm{~g} / \mathrm{L}$ yeast extract, $5 \mathrm{~g} / \mathrm{L}$ tryptone, and $10 \mathrm{~g} / \mathrm{L}$ dextrose) or YNB medium $(10 \mathrm{~g} / \mathrm{L}$ yeast nitrogen base without amino acids, $5 \mathrm{~g} / \mathrm{L}$ ammonia sulfate) supplemented with glucose $(20 \mathrm{~g} / \mathrm{L}, \mathrm{YNBS})$, or xylitol (20 g/L, YNBX). Hygromycin was added to the YPD when necessary to screen transformants. For erythritol fermentation, the enriched medium $\left(\mathrm{YPD}_{300}\right.$ medium) was employed (per L): $300 \mathrm{~g}$ anhydrous glucose, $10 \mathrm{~g}$ yeast extract, $5 \mathrm{~g}$ peptone, $3.5 \mathrm{~g}$ ammonium citrate, $3.0 \mathrm{~g}\left(\mathrm{NH}_{4}\right)_{2} \mathrm{HPO}_{4}, 0.1 \mathrm{~g} / \mathrm{L} \mathrm{MgSO}_{4} \cdot 7 \mathrm{H}_{2} \mathrm{O}$, $0.01 \mathrm{~g} \mathrm{MnSO}_{4} \cdot \mathrm{H}_{2} \mathrm{O}, 0.01 \mathrm{~g} \mathrm{ZnSO}_{4} \cdot 7 \mathrm{H}_{2} \mathrm{O}$ and $0.005 \mathrm{~g}$ $\mathrm{CuSO}_{4} \cdot 5 \mathrm{H}_{2} \mathrm{O}, 0.1 \mathrm{~mL}$ antifoaming agent (organic silicon defoamer), initial $\mathrm{pH}$ 6.5. For solid media, agar $(15 \mathrm{~g} / \mathrm{L})$ was added. The carbon and nitrogen sources were sterilized separately at $121^{\circ} \mathrm{C}$ for $20 \mathrm{~min}$ to avoid the Maillard reaction.

Shake-flask cultures for erythritol production were performed in triplicate using 2-L baffled flasks, each containing $300 \mathrm{~mL}$ enriched medium, at $30^{\circ} \mathrm{C}, 33{ }^{\circ} \mathrm{C}, 34{ }^{\circ} \mathrm{C}$, $35{ }^{\circ} \mathrm{C}$ and $220 \mathrm{rpm}$. Cultures were performed until glucose was depleted. All the baffled Erlenmeyer flasks that contain enriched medium were weighed at the start of fermentation and then before taking sample aliquots for analysis. At the time of sampling, the resulting reduced weight was replenished by the addition of the same weight of sterilized water.

The pilot and large-scale experiment were conducted in $150-\mathrm{L}$ and $30-\mathrm{m}^{3}$ fermentors, which contained $100 \mathrm{~L}$ and $22.5 \mathrm{~m}^{3}$ of the above-enriched medium and fermented at $33^{\circ} \mathrm{C}$ at an agitation of $300 \mathrm{rpm}$ for $150-\mathrm{L}$ fermentor and $100 \mathrm{rpm}$ for $30-\mathrm{m}^{3}$ fermentor, with initial $\mathrm{pH}$ 5.80-6.10 without adjustment during fermentation. The aeration rate maintains between 0.3 to $0.5 \mathrm{vvm}$ during fermentation. At the end of fermentation, erythritol was analyzed by HPLC. Biomass (cell dry weight, CDW) was measured as the optical density of the cultures at $600 \mathrm{~nm}$ absorbance, based on the measurement of $1 \mathrm{~mL}$ medium with $1 \mathrm{OD}_{600}$ unit being equal to $0.25 \mathrm{mg} / \mathrm{mL}$ cell dry weight.

\section{Screening of genes encoding enzymes with D-mannitol/D-arabitol dehydrogenase activities in $Y$. lipolytica CGMCC7326}

Blocking the synthesis pathway of byproducts has critical value in the erythritol industry. To stop the pathway, it is necessary first to identify genes responsible for D-mannitol and D-arabitol synthesis. We used mannitol dehydrogenase (MDH)-like, classical (c) SDRs of nonconventional yeast Scheffersomyces stipitis CBS6054 (XP_001387287) as a query to search the Y. lipolytica CGMCC7326 genome for acquiring the putative mannitol dehydrogenase enzyme gene. We also used the D-arabinitol 2-dehydrogenase gene of Scheffersomyces stipitis CBS6054 (XP_001385035) and Wallemia ichthyophaga, the most halophilic fungus [46] as queries to blast the genome of Y. lipolytica CGMCC7326 for putative $\mathrm{D}$-arabitol dehydrogenase genes. 


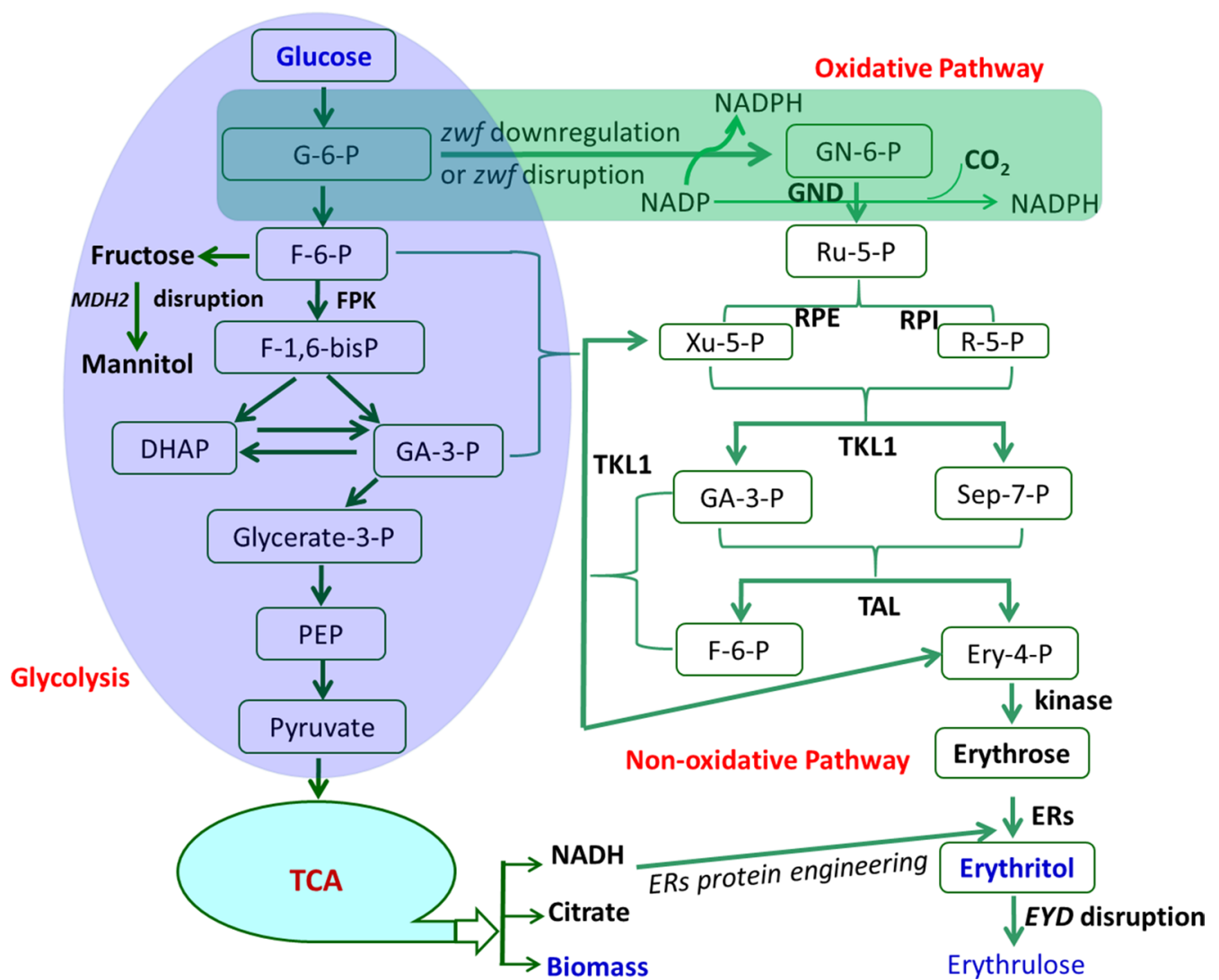

Fig. 9 The putative chart for erythritol biosynthesis from the non-oxidative pathway. In this pathway, the oxidative phosphate pentose pathway (in the green box) was blocked by disrupted zwf gene or downregulated by inhibition of zwf gene expression by replacing its native promoter with a weak or inducible promoter. TKL1 gene was upregulated by overexpression and fructose 6-P and glyceraldehyde 3-P were converted to xylulose 5-P and erythrose 4-P, which is the intermediate of erythritol. Xylulose 5-P can be reversibly converted into ribulose 5-P by RPE, then ribulose 5-P can be converted to ribose 5-P by RPI. Ribose 5-P and xylulose 5-P were converted to fructose 6-P and erythrose 4-P by TKL1 and TAL. The non-oxidative pathway (in pink box) process involves no carbon loss and the carbon atom economy can be improved. NADPH-dependent ERs can be modified by protein engineering to accept NADH as a cofactor, which is generated from the TCA cycle. Since no carbon atom or reduced carbon atom was lost via the oxidative pathway, erythritol production or yield could be further improved

\section{Cloning of the putative mannitol or arabitol dehydrogenase genes in $E$. coli expression vector}

The putative mannitol or arabitol dehydrogenase genes were PCR amplified from the genomic DNA of strain CGMCC7326 using primers listed in Table 1. Forward (F) and reverse (R) primers (name according to gene nomenclature) were designed to introduce NdeI and $X h o I$ sites in the resulting amplicons, respectively. The corresponding PCR fragments were cloned into pET28a expression vector at the NdeI and XhoI sites by Gibson assembly, yielding five plasmids pET28aylAraDH1, pET28a-ylAraDH2, pET28a-ylMDH1, pET28a-ylMDH2, pET28a-ylXDH1. Strain E. coli BL21(DE3) was then transformed with the different constructs containing ylAraDH1, ylAraDH2, ylMDH1, $y l M D H 2$, or $y l X D H 1$ genes.

\section{Enzyme purification}

A single colony of recombinant E. coli BL21 (DE3) was grown in $5 \mathrm{~mL}$ of LB medium with $100-\mu \mathrm{g} \mathrm{mL} \mathrm{m}^{-1}$ kanamycin in $30-\mathrm{mL}$ universal tubes at $37{ }^{\circ} \mathrm{C}$ for $3 \mathrm{~h}$ with shaking at $220 \mathrm{rpm}$. Afterward, $5 \mathrm{~mL}$ of cells were transferred to $245 \mathrm{~mL}$ of LB medium with $100 \mu \mathrm{g} \mathrm{mL}^{-1}$ kanamycin in a 2-L Erlenmeyer flask and incubated at $37{ }^{\circ} \mathrm{C}$ (at $220 \mathrm{rpm}$ ) until the $\mathrm{OD}_{600}$ reached 1.0. After the addition of isopropyl- $\beta$ - D-thiogalactopyranoside (IPTG) at a final concentration of $1 \mathrm{mM}$, the cultures were further incubated at $16^{\circ} \mathrm{C}$ for $24 \mathrm{~h}$. Appropriately, $250 \mathrm{~mL}$ of cells were harvested by centrifugation (at $12,000 \mathrm{~g}$ and $4{ }^{\circ} \mathrm{C}$ for $10 \mathrm{~min}$ ), washed with $100 \mathrm{~mL}$ binding buffer $(20 \mathrm{mM}$ Tris- $\mathrm{HCl}$ pH 8.0, $200 \mathrm{mM} \mathrm{NaCl}, 1 \mathrm{mM}$ PMSF, and $2 \mathrm{mM}$ $\beta$-mercaptoethanol and resuspended in $100 \mathrm{~mL}$ of the same buffer. The cells were disrupted through a continuous high-pressure cell disrupter, and cell debris was eliminated by centrifugation at $10,000 \mathrm{~g}$ for $10 \mathrm{~min}$ at $4{ }^{\circ} \mathrm{C}$. The 
cell extract was filtered through a $0.45-\mu \mathrm{m}$ membrane filter (Millipore).

Recombinant enzymes from cell lysates were purified using Ni-nitrilotriacetate agarose (Ni-NTA) according to the manufacturer's recommendation. Proteins were eluted with a buffer containing $25 \mathrm{mM}$ $\mathrm{NaH}_{2} \mathrm{PO}_{4}-150 \mathrm{mM} \mathrm{NaCl}-200 \mathrm{mM}$ imidazole ( $\mathrm{pH}$ 8.0). The Ni-NTA-purified enzymes were further applied to gel filtration on Sephadex G-25 column equilibrated with $100 \mathrm{mM}$ Tris $-\mathrm{Cl}$ (pH 7.5) containing 1 mM DTT. Protein concentrations were determined spectrophotometrically by the Bradford method with bovine serum albumin as a standard [47]. The purity of prepared enzymes was evaluated by denaturing SDS-PAGE using an acrylamide concentration of $12 \%$ (wt/vol) for the separating gel and $4.5 \%$ (wt/vol) for the stacking gel. Gels were subsequently stained for proteins with Coomassie blue R250 stain and decolored with methanol and acetate.

\section{Determination of enzyme activities}

The determination of enzymes with mannitol dehydrogenase $(\mathrm{MDH})$ activity was carried out as reported earlier [48, 49] with some modifications. MDH activity was measured by monitoring the oxidation of NADH or NADPH (or reduction of NAD or NADP) at $340 \mathrm{~nm}$. The reduction of fructose or fructose 6-P was assayed in $100 \mathrm{mM}$ sodium acetate buffer ( $\mathrm{pH}$ 6.0) containing $2 \mathrm{mM}$ NADPH or NADH, purified enzyme, and $100 \mathrm{mM}$ $\mathrm{D}$-fructose or fructose 6-P in a total volume of $1.5 \mathrm{~mL}$. The reactions were initiated by adding $\mathrm{D}$-fructose or fructose 6-P in the mixtures. The oxidation of mannitol was assayed in $100 \mathrm{mM}$ Tris- $\mathrm{Cl}(\mathrm{pH}$ 8.0) containing $2 \mathrm{mM}$ NADP or NAD, purified enzyme, and $100 \mathrm{mM}$ D-mannitol in a total volume of $1.5 \mathrm{~mL}$. One unit of activity was defined as the amount of enzyme which catalyzes the oxidation of $1 \mu \mathrm{mol}$ of NADPH or NADH per min. For cofactor specificity, enzyme activity for mannitol $(100 \mathrm{mM})$ was determined as described above using cofactor (NAD or NADP) at a concentration of $2 \mathrm{mM}$. To study the substrate specificity, other polyols such as D-sorbitol, D-arabitol, xylitol, ribitol, erythritol, glycerol were also tested. The reaction mixture contained $(1.5 \mathrm{~mL}$ final volume) $50 \mathrm{mM}$ substrate, $2 \mathrm{mM}$ NADP or NAD, 50 $\mu \mathrm{L}$ of purified enzymes, and $10 \mathrm{mM}$ Tris-Cl buffer $(\mathrm{pH}$ 8.0). Specific activity was expressed as $\mathrm{U} / \mathrm{mg}$ of protein.

Transketolase (TKL) activities were assayed by measuring the decrease in NADH concentration at $340 \mathrm{~nm}$ [50]. Briefly, TKL activity was measured at $30{ }^{\circ} \mathrm{C}$ in a reaction mixture with the following composition: $84 \mathrm{mM}$ triethanolamine buffer ( $\mathrm{pH}$ 7.6), $0.9 \mathrm{mM}$ xylulose 5-phosphate, $1.2 \mathrm{mM}$ ribose 5-phosphate, $0.3 \mathrm{mM}$ thiamine pyrophosphate, $0.3 \mathrm{mM} \mathrm{NADH}, 0.34 \mathrm{U}$ of GDH, and $1 \mathrm{U}$ of TIM. In this assay, xylulose 5-phosphate and ribose 5-phosphate are used as substrates for TKL, and the enzymatic formation of glyceraldehyde 3-phosphate in a coupled reaction with GDH and TIM is measured. One unit of enzyme activity was defined as the amount of enzyme that oxidizes $1 \mu \mathrm{mol} \mathrm{NADH}$ per min. These enzyme activities were determined using a UV/VIS-2450 spectrophotometer (Agilent).

\section{Construction of the Ku70 deletion mutant and marker excision}

The $K u 70$ gene of erythritol-producing strain Y. lipolytica CGMCC7326 was $100 \%$ similar to that of Y. lipolytica CLIB122 with gene tag YALIOC08701g. However, the identities of $1.2 \mathrm{~kb}$ upstream sequence of $K u 70$ in CGMCC7326 and CLIB122 was 90\%, the identity of $1.2 \mathrm{~kb}$ downstream sequences of Ku70 in CGMCC7326 and CLIB122 was only $41 \%$, these differences indicating the genome of the two strains are somewhat different. The Ku70 deletion cassette sequence is shown in Additional file 1 (sequence 1), containing the marker gene hygromycin resistance $(h p h)$ gene. The full-length Ku70 deletion cassette $(4.3 \mathrm{~kb})$ was synthesized in vitro and cloned into the pUC19 derivative vector to yield the $K u 70$ gene knockout vector $\mathrm{pSWV}-\Delta K u 70-h p h$, in which two loxP sites were located at the flanking sequence of $h p h$ sequence. Then the Ku70 deletion cassette was cut with $E c o R \mathrm{I}$ and NotI to release the $4.3 \mathrm{~kb}$ fragment, which was transformed into Y. lipolytica CGMCC7326 by lithium acetate transformation [13]. The cells were plated on YPD-hph solid medium containing $400 \mu \mathrm{g} / \mathrm{mL}$ hygromycin B. Transformants were transferred to a new YPD-hph medium, cultivated for 4 days, and repeated to obtain pure clones. Then total genomes of transformants were extracted according to Cheng [51]. Primers $\mathrm{P}_{\text {Ku70-knockout-F }}$ and $\mathrm{P}_{\mathrm{Ku} 70 \text {-knockout- } \mathrm{R}}$ listed in Table 1 were used to verify the $K u 70$ gene disruption. Hph gene marker was rescued from Ku70::hph by transformation with the replicative plasmid pUB4-XDH, in which the Gluconobacter oxydans $621 \mathrm{H}$ xylitol dehydrogenase gene $(X D H)$ was used to replace the $h p h$ gene of pUB4-Cre [18]. The fragment EcoRI-hp4d-621XDH-TT-hp4d-Cre-SalI (sequence 2 in Additional file 1) was synthesized and used to replace the $4050 \mathrm{bp}$ EcoRI-SalI fragment of pUB4-Cre yielding the rescuing plasmid pUB4-XDH. After the plasmid pUB4$\mathrm{XDH}$ rescued the $h p h$ gene, the transformant was cultivated again in YPD liquid medium without hygromycin $B$ and xylitol to lose the episomal plasmid pUB4-XDH, giving rise to the strain ery929 $\triangle K u 70$ (HCY109 in Table 3), which was used as chassis to delete or express other genes, for example, the $U R A 3$ and $E Y D 1$ genes. 


\section{Construction of the URA 3 deletion mutant based on ery929 $\triangle K u 70$ (HCY109)}

To disrupt the $y l U R A 3$ gene in ery929 $\triangle K u 70$ (HCY109), ylURA3 disruption cassette was constructed by overlap PCR. The $1.2 \mathrm{~kb}$ upstream of the $y l U R A 3$ gene (GenBank accession no. YLU40564, $861 \mathrm{bp)}$ was amplified using primers $\mathrm{P}_{\text {URA3-upstream-F }}$ and $\mathrm{P}_{\text {URA3-upstream- } \mathrm{R}}$, the $1.2 \mathrm{~kb}$ downstream of the $y l U R A 3$ gene was amplified using primers $\mathrm{P}_{\text {URA3-downstream-F }}$ and $\mathrm{P}_{\text {URA3-downstream- } \mathrm{R}}$. Then the $1.2 \mathrm{~kb}$ upstream and $1.2 \mathrm{~kb}$ downstream of $y l U R A 3$ fragments were ligated by overlapping PCR with prim-

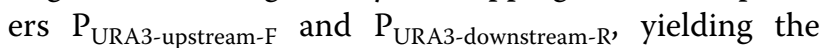
2.4-kb ylURA3 gene disruption cassette and was verified by DNA sequencing. The 2.4-kb fragment was used to transform HCY109 and plated on a solid YPD plate containing $2 \mathrm{mg} / \mathrm{mL}$ fluoroorotic acid (5-FOA) to negatively select $U R A 3$ gene-deleted strains. The transformants grown on 5-FOA containing YPD were transferred to the SD medium without uracil (SD-U) to select stable URA3-deficient mutants. The transformants that were unable to grow on the SD-U plate were verified by PCR with primers $\mathrm{P}_{\text {URA3-verify-F }}$ and $\mathrm{P}_{\text {URA3-verify- } \mathrm{R}}$ to amplify the fragment of $480 \mathrm{bp}$ in the URA3 gene. The authentic URA3 disruption strain was designated as HCY109-2 (ery929 $\triangle K u 70 \triangle U R A 3)$.

\section{Deletion of genes encoding mannitol dehydrogenases and/or D-arabitol dehydrogenases}

Genes encoding the mannitol and D-arabitol dehydrogenases were deleted to verify whether mannitol and D-arabitol can still be synthesized in erythritolproducing $Y$. lipolytica CGMCC7326 (hereinafter as ery929). Five genes were identified to have both mannitol and D-arabitol dehydrogenase activities in ery929 genome: (1) D-arabitol dehydrogenase gene 1 (AraDH1, gene locus was g1595.t1 in ery929 and its counterpart is YALI0F02211g in Y. lipolytica CLIB122 CLIB122), (2) D-arabitol dehydrogenase gene 2 (AraDH2, gene locus was g3858.t1 in ery929, and its counterpart is YALIOE05643g in CLIB122), (3) D-mannitol dehydrogenase gene 1 (MDH1, gene locus was g5130.t1 in ery929, its counterpart is YALI0B16192g in CLIB122), (4) D-mannitol dehydrogenase gene 2 ( $\mathrm{MDH} 2$, gene locus was g2069.t1 in ery929, its counterpart is YALI0D18964g in CLIB122), and (5) xylitol dehydrogenase gene (XDH1, gene locus was g4121.t1 in ery929, its counterpart is YALIOE12463g in CLIB122).

The sequences of the five genes deletion cassettes are shown in the Additional file 1. All genes contained the marker gene hygromycin resistance $(h p h)$ gene, full-length synthesized in vitro, and cloned into the pUC19 derivative vector to yield the corresponding gene knockout vector, in which two loxp sites were located at the flanking sequence of $h p h$ sequence. For instance, AraDH1 gene knockout cassette $(1.5 \mathrm{~kb}$ upstream of AraDH1-loxP-hph-loxP-1.5 kb downstream) (total $4.4 \mathrm{~kb}$ ) was synthesized and cloned into pUC19-derived vector to yield AraDH1 gene knockout vector pSWV-AAraDH1-hph (sequence 3 in Additional file 1). Similarly, the other four knockout vectors were constructed in the same strategy. Then the knockout vectors were linearized with EcoRI and NotI to release the knockout cassettes and were transformed into HCY109 (Y. lipolytica ery929 $\Delta K u 70$ ), respectively. The identification of deletion mutants was verified according to the above method using the primers listed in Table 1. The identified AraDH1, AraDH2, MDH1, $M D H 2, X D H 1$ gene-deleted mutants were designated as ery929 $\triangle$ Ku70 $\Delta u r a 3 \triangle A r a D H 1$

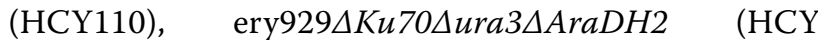

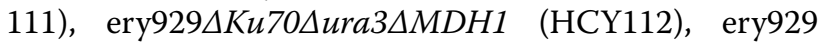
$\triangle K u 70 \Delta u r a 3 \Delta M D H 2 \quad$ (HCY113), ery929 $\triangle K u$ $70 \Delta u r a 3 \triangle X D H 1$ (HCY114).

\section{Functional identification of mutants deficient in yIAraDH1, yIAraDH2, yIMDH1, yIMDH2 or yIXDH1 genes}

To verify whether ylAraDH1, ylAraDH1, ylMDH1, $y l M D H 2$, and $y l X D H 1$ gene deletion can block byproducts mannitol or D-arabitol synthesis during the erythritol fermentation, the wild-type $Y$. lipolytica CGMCC7326 and mutant strains (HCY110, HCY111, HCY112, HCY113, and HCY114) were inoculated in $\mathrm{YPD}_{300}$ medium for erythritol synthesis. Shake-flask cultures for erythritol production were performed in triplicate using 2-L baffled flasks containing $250 \mathrm{~mL}$ rich medium $\left(\mathrm{YPD}_{300}\right)$, at $30{ }^{\circ} \mathrm{C}$ and $220 \mathrm{rpm}$. Cultures were performed until glucose was depleted.

\section{Construction of EYD1 gene-deletion mutants and marker excision}

The EYD1 gene knockout cassette was also synthesized and contained the marker hygromycin resistance gene $(h p h)$ gene, in which two loxP sites were located at the flanking sequence of $h p h$ sequence. The synthesized cassette was cloned into the pUC19 derivative vector to yield pWSV-EYD1-loxP-hph-loxP (sequence 8 in Additional file 1), which was cut with EcoRI and NotI to release the $4.3 \mathrm{~kb}$ fragment to transform the strain HCY113 ( $\triangle K u 70 \triangle$ ura $3 \triangle M D H 2)$. Identification of $E Y D 1$ genedeletion mutants was verified according to the above method using the primers $\mathrm{P}_{\text {EYD1- knockout }-\mathrm{F}}$ and $\mathrm{P}_{\mathrm{EYD1}}$ knockout $-\mathrm{R}$ listed in Table 3. The transformation of plasmid pHB4-621XDH rescued the $h p h$ gene. The identified EYD1 gene-deleted mutants were designated as HCY115 
(quadruple mutant, $\triangle K u 70 \triangle u r a 3 \triangle M D H 2 \triangle E Y D 1$ ). The fermentation verification of the HCY115 strain was performed as the method used above.

\section{Overexpression of S. cerevisiae RSP5 gene to improve thermoresistance of $\mathrm{HCY} 115$ strain}

The ubiquitin ligase gene RSP5 of $S$. cerevisiae [35] was overexpressed in HCY115 $(\triangle K u 70 \triangle$ ura $3 \triangle M D H 2 \triangle E Y D 1)$. The $S$. cerevisiae RSP5 gene was cloned into the pINA1313 vector to give plasmid pINA1313-ScRSP5 (containing ura3 marker), which was cut with NotI to linearize this plasmid, then transformed to HCY115 strain, and was plated on YPD and cultivated at $34{ }^{\circ} \mathrm{C}$. PCR verified transformants with the pair of primers $\mathrm{P}_{\mathrm{ScRSP} 5-\mathrm{F}}$ and $\mathrm{P}_{\mathrm{ScRSP5}-\mathrm{R}}$. The corrected strain was designated as HCY117 ( $\triangle K u 70 \triangle M D H 2 \triangle E Y D 1::$ ScRSP5, no longer ura3-deficient due to revertant by ura3 gene in pINA1313). The erythritol fermentation and growth of the HCY117 strain were evaluated in the medium $\mathrm{YPD}_{300}$ at $30^{\circ} \mathrm{C}$ to $35^{\circ} \mathrm{C}$.

\section{Overexpression of genes ZWF1 and GND1 in HCY117} ZWF1 (YALIOE22649g) and GND1 (YALIOB15598g) genes from $Y$. lipolytica were overexpressed in the HCY117 strain using NotI treated ZWF-GND expression cassette (5'-26S rDNA-hp4d-zwf1-TT-hph-hp4d-gnd1$T T-26 S$ rDNA-3', (Sequence 9 in Additional file 1), transformed into HCY117 and plated onto YPDH medium (YPD $+400 \mu \mathrm{g} / \mathrm{mL}$ hygromycin). Transformants grown on this medium were identified by PCR to verify the extra $Z W F-G N D$ gene and to verify their expression level by qPCR. The true strain was designated as HCY 118 ( $\triangle K u 70 \triangle M D H 2 \triangle E Y D 1:: S c R S P 5::$ ZWF1-GND1). The erythritol fermentation and growth of the HCY118 strain were evaluated in the medium $\mathrm{YPD}_{300}$ at $30-35^{\circ} \mathrm{C} \mathrm{com}$ pared with the wild-type strain CGMCC7326 (ery929).

\section{RNA isolation and transcript-level quantification}

Shake-flask cultures were grown in rich medium. Cells were collected at an $\mathrm{OD}_{600}$ of 2.0 and stored at $-80{ }^{\circ} \mathrm{C}$ in the Trizol solution. Total RNAs were extracted using liquid nitrogen and the TRIzol kit from Sangon Biotech (Shanghai, China). cDNA was obtained using HiScript ${ }^{\circledR}$ III-RT SuperMix for qPCR with gDNA wiper (Vazyme Biotech Co., Ltd). These cDNA samples were used as templates for real-time PCR analysis (qRT-PCR) with the specific primer sets listed in Table 1 . The qRT-PCRs were performed using ChamQ ${ }^{\mathrm{TM}}$ Universal $\mathrm{SYBR}^{\circledR} \mathrm{qPCR}$ Master Mix (Vazyme Biotech Co., Ltd) and ABI7500 Real-Time PCR system. The qPCRs proceeded as follows: initial denaturation at $94{ }^{\circ} \mathrm{C}$ for $1 \mathrm{~min}$, followed by 40 cycles of denaturation at $94{ }^{\circ} \mathrm{C}$ for $10 \mathrm{~s}$, annealing at $62{ }^{\circ} \mathrm{C}$ for $30 \mathrm{~s}$, and elongation at $72{ }^{\circ} \mathrm{C}$ for $20 \mathrm{~s}$. Specific amplification was confirmed by analysis of melting curves from $65^{\circ} \mathrm{C}$ to $95^{\circ} \mathrm{C}$. Gene expressions were normalized to that of the $\beta$-actin gene ( $\Delta C_{T}$ method). The fold differences in gene expression between the transformants and the control strains CGMCC7326 were calculated by the $2^{-\Delta \Delta C T}$ method. All samples were analyzed in triplicate.

\section{Analytical methods}

Sugars and polyols were quantified by HPLC using a refractive index detector (Shodex RI101) and a Shodex SP0810 ion exclusion column $(300 \times 8 \mathrm{~mm})$. Elution was performed at $70{ }^{\circ} \mathrm{C}$ using pure water at a flow rate of $1 \mathrm{~mL} / \mathrm{min}$. The mass yield of erythritol $\left(Y_{\text {ery }}\right)$ was expressed in $\mathrm{g} / \mathrm{g}$ from glucose and was calculated from the equation $Y_{\text {ery }}=P / S$. The volumetric productivity $\left(Q_{\text {ery }}\right)$ was expressed in $\mathrm{g} / \mathrm{L} \cdot \mathrm{h}$ and was calculated from $Q_{\text {ery }}=P / V \cdot t$, where $P$ is the amount of erythritol in the culture liquid at the end of fermentation (g); $S$ is the total amount of glucose consumed (g); $V$ is the initial volume of culture liquid (L), and $t$ is the culture time (h). Glucose consumption rate $\left(R_{\text {glu }}\right)$ was calculated as the amount of glucose consumed per hour and per liter of culture medium.

\section{Supplementary information}

Supplementary information accompanies this paper at https://doi. org/10.1186/s13068-020-01815-8.

Additional file 1

\section{Acknowledgements}

Not applicable

Authors' contributions

$\mathrm{HC}$ designed the experiments, wrote, and revised the manuscript. NW, PC, $Y Z, S X$, and $Y X$ performed the experiments. MB discussed and revised the manuscript. PF participated in results analysis and interpretation and revised the manuscript. All authors read and approved the final manuscript.

\section{Funding}

The National Key Research and Development Program of China [2018YFA0900700] financially supported this work.

Availability of data and materials

The authors promise the availability of data and material.

Ethics approval and consent to participate

Not applicable.

Consent for publication

The authors have consented for publication.

Competing interests

The authors declare that they have no competing interests. 


\begin{abstract}
Author details
1 State Key Laboratory of Microbial Metabolism, and School of Life Sciences and Biotechnology, Shanghai Jiao Tong University, Shanghai, China. ${ }^{2}$ School of Life Science and Food Engineering, Huaiyin Institute of Technology, Huaian 223003, China. ${ }^{3}$ Microbial Process and Interaction, TERRA Teaching and Research Centre, University of Liege - Gembloux Agro-Bio Tech, Gembloux, Belgium.
\end{abstract}

Received: 16 June 2020 Accepted: 10 October 2020 Published online: 16 November 2020

\section{References}

1. Chan TF, Lin WT, Huang HL, Lee CY, Wu PW, Chiu YW, Huang CC, Tsai S, Lin $\mathrm{CL}$, Lee $\mathrm{CH}$. Consumption of sugar-sweetened beverages is associated with components of the metabolic syndrome in adolescents. Nutrients. 2014;6(5):2088-103.

2. Bray GA, Popkin BM. Dietary sugar and body weight: have we reached a crisis in the epidemic of obesity and diabetes?: health be damned! Pour Sugar Diabetes Care. 2014;37(4):950-6.

3. Yokozawa T, Kim HY, Cho EJ. Erythritol attenuates the diabetic oxidative stress through modulating glucose metabolism and lipid peroxidation in streptozotocin-induced diabetic rats. J Agri Food Chem. 2002;50(19):5485-9.

4. Wölnerhanssen BK, Meyer-Gerspach AC, Beglinger C, Islam MS. Metabolic effects of the natural sweeteners xylitol and erythritol: a comprehensive review. Crit Rev Food Sci Nutr. 2019;16:1-13.

5. den Hartog GJ, Boots AW, Adam-Perrot A, Brouns F, Verkooijen IW, Weseler AR, Haenen GR, Bast A. Erythritol is a sweet antioxidant. Nutr. 2010;26(4):449-58.

6. Boesten DM, Berger A, de Cock P, Dong H, Hammock BD, den Hartog GJ, Bast A. Multi-targeted mechanisms underlying the endothelial protective effects of the diabetic-safe sweetener erythritol. PLOS ONE. 2013;8(6):e65741.

7. Kobayashi Y, Iwata H, Mizushima D, Ogihara J, Kasumi T. Erythritol production by Moniliella megachiliensis using nonrefined glycerol waste as carbon source. Lett Appl Microbiol. 2015;60(5):475-80.

8. Lee JK, Koo BS, Kim SY. Fumarate-mediated inhibition of erythrose reductase, a key enzyme for erythritol production by Torula corallina. Appl Environ Microbiol. 2002;68(9):4534-8.

9. Wang S, Wang H, Lv J, Deng Z, Cheng H. Highly efficient erythritol recovery from waste erythritol mother liquid by yeast-mediated biopurification. J Agric Food Chem. 2017;65:11020-8

10. Kang P, Li L, Yan L, Ju X, Hu C, Yao X. Enhancement of erythritol production in Trichosporonoides oedocephalis by regulating cellular morphology with betaine. Chem Pap. 2019;73:2065-72.

11. JanekT, Dobrowolski A, Biegalska A, Mirończuk AM. Characterization of erythrose reductase from Yarrowia lipolytica and its influence on erythritol synthesis. Microb Cell Fact. 2017;16(1):118.

12. Carly F, Vandermies M, Telek S, Steels S, Thomas S, Nicaud JM, Fickers P. Enhancing erythritol productivity in Yarrowia lipolytica using metabolic engineering. Met Eng. 2017;42:19-24.

13. Cheng H, Wang S, Bilal M, Ge X, Zhang C, Fickers P, Cheng H. Identification, characterization of two NADPH-dependent erythrose reductases in the yeast Yarrowia lipolytica and improvement of erythritol productivity using metabolic engineering. Microb Cell Fact. 2018;17:133.

14. Abdel-Mawgoud AM, Markham KA, Palmer CM, Liu N, Stephanopoulos G, Alper HS. Metabolic engineering in the host Yarrowia lipolytica. Met Eng. 2018;50:192-208.

15. Lustig AJ. The kudos of non-homologous end-joining. Nat Genet. 1999;23:130-1.

16. Verbeke J, Beopoulos A, Nicaud JM. Efficient homologous recombination with short length flanking fragments in Ku70 deficient Yarrowia lipolytica strains. Biotechnol Lett. 2013;35:571-6.

17. Wu Y, Xu S, Gao X, Li M, Li D, Lu W. Enhanced protopanaxadiol production from xylose by engineered Yarrowia lipolytica. Microb Cell Fact. 2019;18:83.

18. Fickers P, Le Dall MT, Gaillardin C, Thonart P, Nicaud JM. New disruption cassettes for rapid gene disruption and marker rescue in the yeast Yarrowia lipolytica. J Microbiol Methods. 2003;55:727-37.
19. Tomaszewska L, Rywinska A, Gładkowski W. Production of erythritol and mannitol by Yarrowia lipolytica yeast in media containing glycerol. J Ind Microbiol Biotechnol. 2012;39:1333-43.

20. Tomaszewska L, Rakicka M, RymowiczW, Rywinska A. A comparative study on glycerol metabolism to erythritol and citric acid in Yarrowia lipo/ytica yeast cells. FEMS Yeast Res. 2014;14:966-76.

21. Rakicka M, Biegalska A, Rymowicz W, Dobrowolski A, Mirończuk AM. Polyol production from waste materials by genetically modified Yarrowia lipolytica. Bioresour Technol. 2017;243:393-9.

22. Sekova VY, Dergachevaa DI, Tereshinab VM, Isakovaa EP, Deryabinaa Yul. Carbohydrate spectrum of extremophilic yeasts Yarrowia lipolytica under pH stress. Microbiology. 2018;87(2):173-82 (Printed in Russia).

23. Dulermo T, Lazar Z, Dulermo R, Rakicka M, Haddouche R, Nicaud JM. Analysis of ATP-citrate lyase and malic enzyme mutants of Yarrowia lipolytica points out the importance of mannitol metabolism in fatty acid synthesis. Biochim Biophys Acta. 2015;1851(9):1107-17.

24. Napora K, Wrodnigg TM, Kosmus P, Thonhofer M, Robins K, Winkler M. Yarrowia lipolytica dehydrogenase/reductase: an enzyme tolerant for lipophilic compounds and carbohydrate substrates. Bioorg Med Chem Lett. 2013:23(11):3393-5.

25. Rodriguez GM, Hussain MS, Gambill L, Gao D, Yaguchi A, Blenner M. Engineering xylose utilization in Yarrowia lipolytica by understanding its cryptic xylose pathway. Biotechnol Biofuels. 2016;9:149.

26. Niang PM, Arguelles-Arias A, Steels S, Denies O, Nicaud JM, Fickers P. In Yarrowia lipolytica erythritol catabolism ends with erythrose phosphate. Cell Biol Int. 2020;44:651-60.

27. Carly F, Gamboa-Melendez H, Vandermies M, Damblon C, Nicaud JM, Fickers P. Identification and characterization of EYK1, a key gene for erythritol catabolism in Yarrowia lipolytica. Appl Microbiol Biotechnol. 2017;101(17):6587-96.

28. Carly F, Steels S, Telek S, Vandermies M, Nicaud JM, Fickers P. Identification and characterization of EYD1, encoding an erythritol dehydrogenase in Yarrowia lipolytica and its application to bioconvert erythritol into erythrulose. Bioresour Technol. 2018;247:963-9.

29. Lane S, Zhang S, Wei N, Rao C, Jin YS. Development and physiological characterization of cellobiose-consuming Yarrowia lipolytica. Biotechnol Bioeng. 2015;112(5):1012-22.

30. Nunomura K, Fujita T. Calorimetric study on the sugar metabolism of yeast under nongrowing conditions. J Gen Appl Microbial. 1982;28:479-90.

31. Gao C, Jiang B, Wang Y, Liu G, Yang C. Overexpression of a heat shock protein (ThHSP18.3) from Tamarix hispida confers stress tolerance to yeast. Mol Biol Rep. 2012;39(4):4889-97.

32. Glatz A, Pilbat AM, Németh GL, Vince-Kontár K, Jósvay K, Hunya Á, Udvardy A, Gombos I, Péter M, Balogh G, Horváth I, Vígh L, Török Z. Involvement of small heat shock proteins, trehalose, and lipids in the thermal stress management in Schizosaccharomyces pombe. Cell Stress Chaperones. 2016;21(2):327-38.

33. Li P, Fu X, Zhang L, Zhang Z, Li J, Li S. The transcription factors Hsf1 and Msn2 of thermotolerant Kluyveromyces marxianus promote cell growth and ethanol fermentation of Saccharomyces cerevisiae at high temperatures. Biotechnol Biofuels. 2017;10:289.

34. Xiao W, Duan X, Lin Y, Cao Q, Li S, Guo Y, Gan Y, Qi X, Zhou Y, Guo L, Qin P, Wang Q, Shui W. Distinct proteome remodeling of industrial Saccharomyces cerevisiae in response to prolonged thermal stress or transient heat shock. J Proteome Res. 2018;17(5):1812-25.

35. Shahsavarani H, Sugiyama M, Kaneko Y, Chuenchit B, Harashima S. Superior thermotolerance of Saccharomyces cerevisiae for efficient bioethanol fermentation can be achieved by overexpression of RSP 5 ubiquitin ligase. Biotechnol Adv. 2012;30:1289-300.

36. Sekova VY, Gessler NN, Isakova EP, Antipov AN, Dergacheva DI, Deryabina YI, Trubnikova EV. Redox status of extremophilic yeast Yarrowia lipolytica during adaptation to pH-stress. Appl Biochem Microbiol. 2015;51:649-54.

37. Meena M, Prasad V, Zehra A, Gupta VK, Upadhyay RS. Mannitol metabolism during pathogenic fungal-host interactions under stressed conditions. Front Microbiol. 2015;6:1019.

38. Manabu SAMI. The Alkaline methylene blue staining method for yeast activity determination. J Ferment Bioeng. 1995;90(7):536-41.

39. Patel TK, Williamson JD. Mannitol in plants, fungi, and plant-fungal interactions. Trends Plant Sci. 2016;21:486-97. 
40. Chaturvedi V, Bartiss A, Wong B. Expression of bacterial mtID in Saccharomyces cerevisiae results in mannitol synthesis and protects a glycerol-defective mutant from high-salt and oxidative stress. J Bacteriol. 1997;179(1):157-62.

41. Nogae I, Johnston M. Isolation and characterization of the ZWF1 gene of Saccharomyces cerevisiae, encoding glucose-6-phosphate dehydrogenase. Gene. 1990;96:161-9.

42. Mirończuk AM, Biegalska A, Dobrowolski A. Functional overexpression of genes involved in erythritol synthesis in the yeast Yarrowia lipolytica. Biotechnol Biofuels. 2017;10:77.

43. Rywińska A, Tomaszewska L, Rymowicz W. Erythritol biosynthesis by Yarrowia lipolytica yeast under various culture conditions. Afr J Microbiol Res. 2013;27:3511-6.

44. Kamzolova SV, Shishkanova NV, Morgunov IG, Finogenova TV. Oxygen requirements for growth and citric acid production of Yarrowia lipolytica. FEMS Yeast Res. 2003;3(2):217-22.

45. Guo W, Huang Q, Feng Y, Tan T, Niu S, Hou S, Chen Z, Du Z, Shen Y, Fang X. Rewiring central carbon metabolism for tyrosol and salidroside production in Saccharomyces cerevisiae. Biotechnol Bioeng. 2020. https://doi. org/10.1002/bit.27370.

46. Zajc J, Kogej T, Galinski EA, Ramos J, Gunde-Cimerman N. Osmoadaptation strategy of the most halophilic fungus, Wallemia ichthyophaga, growing optimally at salinities above 15\% NaCl. Appl Environ Microbiol. 2014;80(1):247-56.

47. Bradford MM. A rapid and sensitive method for the quantification of microgram quantities of protein utilizing the principle of protein-dye binding. Anal Biochem. 1976;72:248-54.

48. Stoop JMH, Williamson JD, Pharr DM. Mannitol metabolism in plants: a method for coping with stress. Trends Plant Sci. 1996:5:139-44.

49. Stoop JMH, Pharr DM. Mannitol metabolism in celery stressed by excess macronutrients. Plant Physiol. 1994;106:503-11.

50. Matsushika A, Inoue H, Watanabe S, Kodaki T, Makino K, Sawayama S. Efficient bioethanol production by a recombinant flocculent Saccharomyces cerevisiae strain with a genome-integrated NADP+-dependent xylitol dehydrogenase gene. Appl Environ Microbiol. 2009;75(11):3818-22.

51. Cheng HR, Jiang N. Extremely rapid extraction of DNA from bacteria and yeasts. Biotechnol Lett. 2006;28(1):35-9.

\section{Publisher's Note}

Springer Nature remains neutral with regard to jurisdictional claims in published maps and institutional affiliations.
Ready to submit your research? Choose BMC and benefit from:

- fast, convenient online submission

- thorough peer review by experienced researchers in your field

- rapid publication on acceptance

- support for research data, including large and complex data types

- gold Open Access which fosters wider collaboration and increased citations

- maximum visibility for your research: over $100 \mathrm{M}$ website views per year

At BMC, research is always in progress.

Learn more biomedcentral.com/submissions 